\title{
Cardiac electrophysiology in mice: a matter of size
}

\author{
Sven Kaese ${ }^{1}$ and Sander Verheule ${ }^{2 *}$ \\ Division of Experimental and Clinical Electrophysiology, Department of Cardiology and Angiology, University Hospital Münster, Münster, Germany \\ 2 Department of Physiology, Faculty of Medicine, Maastricht University, Maastricht, Netherlands
}

\section{Edited by:}

Carol Ann Remme, University of Amsterdam, Netherlands

Reviewed by:

Morten B. Thomsen, University of

Copenhagen, Denmark

Bas Boukens, Academic Medical

Center, Netherlands

Steven Pogwizd, University of

Alabama at Birmingham, USA

Yoram Etzion, Ben-Gurion University

of the Negev Beer-Sheva, Israel

\section{*Correspondence.}

Sander Verheule, Department of

Physiology, Universiteitssingel 50,

P.O. Box 616, 6200 MD, Maastricht,

Netherlands.

e-mail: s.verheule@

maastrichtuniversity.nl
Over the last decade, mouse models have become a popular instrument for studying cardiac arrhythmias. This review assesses in which respects a mouse heart is a miniature human heart, a suitable model for studying mechanisms of cardiac arrhythmias in humans and in which respects human and murine hearts differ. Section I considers the issue of scaling of mammalian cardiac (electro) physiology to body mass. Then, we summarize differences between mice and humans in cardiac activation (section II) and the currents underlying the action potential in the murine working myocardium (section III). Changes in cardiac electrophysiology in mouse models of heart disease are briefly outlined in section $\mathrm{IV}$, while section $\mathrm{V}$ discusses technical considerations pertaining to recording cardiac electrical activity in mice. Finally, section VI offers general considerations on the influence of cardiac size on the mechanisms of tachy-arrhythmias.

Keywords: arrhythmias, atrial fibrillation, conduction, mouse, scaling, ventricular fibrillation

\section{SCALING OF CARDIAC PHYSIOLOGY TO BODY MASS}

Body mass varies between small mammals like the mouse $(0.03 \mathrm{~kg}$, see Table 1$)$ to the largest mammal, the blue whale $\left(30,000 \mathrm{~kg}\right.$ ) by a factor of $10^{6}$ (Noujaim et al., 2004). Very diverse physiological parameter such as basal metabolic rate, life span, left ventricular ejection time, and ECG time intervals (RR, PR, QRS, and QT) scale with body mass (BM) (West et al., 1997, 1999; Noujaim et al., 2004, 2007; Popovic et al., 2005). The "universal law of allometric scaling" for a parameter $\mathbf{P}$ is expressed by the allometric equation: $\mathbf{P}=\mathbf{a B M}^{\mathbf{b}}$ (West et al., 1997, 1999; Noujaim et al., 2007), where $\boldsymbol{a}$ is a normalization constant and $\boldsymbol{b}$ represents the scaling exponent. Frequently, $\boldsymbol{b}$ is a multiple of $1 / 4$. Basal metabolic rate scales as $\mathrm{BM}^{3 / 4}$ (West et al., 1997, 1999 ) and is thought to be related to the ratio of body surface area to body volume. A larger body surface-to-volume ratio results in faster temperature loss of the body and thus requires a higher basal metabolic rate to maintain body temperature. Mice, with a high surface-to-volume ratio, tend to have a relatively high basal metabolic rate (see Table 1). Adequate blood pressure is required to maintain homeostasis and basal metabolic rate. The mean arterial pressure does not scale with body mass and is thus similar between mice and humans (West et al., 1997; Janssen and Smits, 2002). By contrast, cardiac output (CO, exponent $3 / 4$ ), cardiac stroke volume (SV, exponent 1 ), blood volume (exponent 1 ) and circulation time (exponent 1/4) (West et al., 1997; Janssen and Smits, 2002) scale with BM. In mice, CO amounts to $0.0085-0.027 \mathrm{~L} / \mathrm{min}$ (Table 1) and thus the murine blood volume of $0.002-0.003 \mathrm{~L}$ can circulate around 3-14 times per minute. Humans have a $\mathrm{CO}$ of $4-8 \mathrm{~L} / \mathrm{min}$ and a blood volume of 4.5-5.5 (Table 1), which circulates circa 1-2 times per minute. The cardiac index $(\mathrm{CI})$ relates $\left(\mathrm{CO}=\mathrm{SV}^{*} \mathrm{HR}\right)$ to body surface area $(\mathrm{CI}=\mathrm{CO} /$ body surface area). This hemodynamic parameter represents cardiac performance normalized to body surface area and thus indirectly to basal metabolic rate. The cardiac index is tenfold higher in mice than in humans (Janssen and Smits, 2002), reflecting a higher basal metabolic rate in mice. Normalized SV is similar between mice and humans at around $1 \mu \mathrm{l} / \mathrm{g}$ body weight. Therefore, the difference in HR is mainly responsible for differences in CI.

Over the entire range of BM form mice to whales, cardiac mass amounts $0.6 \%$ of body mass (Prothero, 1979) and cardiac gross anatomy is remarkably similar, with comparable pacemaking and conduction structures (Wessels and Sedmera, 2003). Using the same biochemical processes to ensure optimal electromechanical function, hearts of very different sizes have to maintain sufficient cardiac function under a variety of conditions. Resting heart rates in conscious mice (measured by telemetry) range from 550 to 725 beats per minute (bpm) (Kass et al., 1998; Gehrmann et al., 2000; Janssen and Smits, 2002; Fabritz et al., 2010), corresponding to a sinus cycle length (SCL) of $80-110 \mathrm{~ms}$. Because cardiac conduction velocities are not strongly dependent on BM (Table 1 and Figure 1), the timing intervals of the ECG scale with the propagation distance, i.e., cardiac size. The ECG time intervals RR, PR, QRS, and QT scale with $\mathrm{BM}^{1 / 4}$ (Noujaim et al., 2004, 2007) and consequently heart rate scales with body mass with an exponent of -1/4 (West et al., 1997; Janssen and Smits, 2002; Noujaim et al., 2004). The PR interval represents electrical conduction from the atrium through the AV node and His-Purkinje system to the ventricles and thus can be seen as a fractal network with three separate components, the $\mathrm{PA}, \mathrm{AH}$, and $\mathrm{HV}$ subintervals, that also scale with body mass with an exponent of $1 / 4$ (Noujaim et al., 2004). Hence, percentage of each subinterval to the $P R$ interval is constant and independent of body and heart size (Noujaim et al., 2004). 
Table 1 | Comparison of mouse and human (cardiac) physiology.

\begin{tabular}{|c|c|c|c|c|}
\hline & Human & References & Mouse & References \\
\hline Body mass (kg) & $58-85$ & $\begin{array}{l}\text { de la Grandmaison et al., 2001; Stein } \\
\text { et al., 2002; Noujaim et al., 2004; } \\
\text { Johnstone et al., 2005; Kasper et al., } \\
\text { 2008; Later et al., 2010; Barnes et al., } \\
2012\end{array}$ & $0.015-0.043$ & $\begin{array}{l}\text { Sheng et al., 1999; Verheule et al., 1999; VanderBrink } \\
\text { et al., 2000; Janssen and Smits, 2002; Speakman } \\
\text { et al., 2002; Noujaim et al., 2004; Xiao et al., 2004; } \\
\text { Muller et al., 2005; Hong et al., 2008; Barwe et al., } \\
\text { 2009; Brands et al., 2010; Carlstrom et al., 2010; Gros } \\
\text { et al., 2010; Carroll et al., } 2011\end{array}$ \\
\hline Lifespan (year) & $70-80$ & Zhang and Zhang, 2009 & $2-2.5$ & Speakman et al., 2002; Zhang and Zhang, 2009 \\
\hline Basal metabolic rate $(\mathrm{kJ} / \mathrm{d})$ & 6279 & Johnstone et al., 2005 & 15.6 & Speakman et al., 2002 \\
\hline $\begin{array}{l}\text { Basal metabolic rate }(\mathrm{O} 2 \\
\text { consumption } \mathrm{L} /\left(\mathrm{kg}^{*} \mathrm{~h}\right)\end{array}$ & 0.9 & Janssen and Smits, 2002 & $0.8-3$ & Desai et al., 1997; Janssen and Smits, 2002 \\
\hline
\end{tabular}

\section{HEART}

Heart weight (g)

de la Grandmaison et al., 2001; Cunha

et al., 2002; Janssen and Smits, 2002;

Later et al., 2010

Heart weight/body weight ratio $(\mathrm{kg} / \mathrm{kg})$

0.004-0.006 de la Grandmaison et al., 2001; Cunha et al., 2002; Later et al., 2010

\section{HEMODYNAMIC}

Stroke volume $(\mathrm{mL})$

50-100

Jans

Cardiac output (L/min) $\quad 4-8$

$4-8$

Blood pressure (mean

88-100

arterial pressure, $\mathrm{mmHg}$ )

Blood volume (L)

$5-6$

\section{CARDIAC EP}

Heart rate (beats/min)

56-101

PR interval (ms)

$120-200$

\section{Janssen and Smits, 2002;
2005; Kasper et al., 2008}

Janssen and Smits, 2002; Mestas and
Hughes, 2004; Meijler et al., 2005;

$0.12-0.17$

Muller et al., 2005; Hong et al., 2008; Barwe et al., 2009; Carlstrom et al., 2010; Carroll et al., 2011 Kasper et al., 2008

Mancia et al., 1983; Janssen and Smits, 73-125 2002; Barnes et al., 2012; Damkjaer et al., 2012

Janssen and Smits, 2002; Mestas and 0.002-0.03 Hughes, 2004; Kasper et al., 2008

Edvardsson et al., 1984; Franz et al., 1987; Janssen and Smits, 2002; Stein et al., 2002; Noujaim et al., 2004; Monnig et al., 2005; Zhang and Zhang, 2009; Barnes et al., 2012; Rich et al., 2012

PR interval (ms)

Stein et al., 2002; Waldek, 2003; Noujaim et al., 2004; Kasper et al., 2008; Grecu et al., 2009

$30-56$

$500-724$

(1)
0.004-0.005 Muller et al., 2005; Hong et al., 2008; Barwe et al.,
2009; Carlstrom et al., 2010; Carroll et al., 2011 Janssen and Smits, 2002; Fabritz et al., 2010; Gros et al., 2010; Hyyti et al., 2010; Maslov et al., 2010

Janssen and Smits, 2002; Mestas and Hughes, 2004; Gros et al., 2010; Maslov et al., 2010

Kass et al., 1998; Sheng et al., 1999; Janssen and Smits, 2002; Brands et al., 2010; Carlstrom et al., 2010

Sheng et al., 1999; Janssen and Smits, 2002; Mestas and Hughes, 2004

\section{Kass et al., 1998; Gehrmann et al., 2000; Janssen and Smits, 2002; Xiao et al., 2004; Fabritz et al., 2010}

\begin{abstract}
QRS duration (ms)
84-110

Kasper et al., 2008; Grecu et al., 2009;

Rich et al., 2012
\end{abstract}

QT (ms)

385

Rich et al., 2012

29-109
Thomas et al., 1998; Jalife et al., 1999; Morley et al., 1999; Vaidya et al., 1999; VanderBrink et al., 1999, 2000; Verheule et al., 1999; Gehrmann et al., 2000; Maguire et al., 2000; Saba et al., 2000; Tamaddon et al., 2000; Wehrens et al., 2000; Li et al., 2004, 2009; Noujaim et al., 2004; Saba et al., 2005; Zhang et al., 2005; Sawaya et al., 2007; Mancarella et al., 2008; Stein et al., 2009

Thomas et al., 1998; Jalife et al., 1999; Morley et al., 1999; Vaidya et al., 1999; VanderBrink et al., 1999, 2000; Verheule et al., 1999; Gehrmann et al., 2000; Maguire et al., 2000; Saba et al., 2000; Tamaddon et al., 2000; Wehrens et al., 2000; Schrickel et al., 2002; Alcolea et al., 2004; Xiao et al., 2004; Saba et al., 2005; Sawaya et al., 2007; Schrickel et al., 2007; Stein et al., 2009; Gros et al., 2010

Thomas et al., 1998; Jalife et al., 1999; Morley et al., 1999; Vaidya et al., 1999; VanderBrink et al., 1999; Gehrmann et al., 2000; Maguire et al., 2000; Saba et al., 2000; VanderBrink et al., 2000; 
Table 1 | Continued.

\begin{tabular}{|c|c|c|c|}
\hline Human & References & Mouse & References \\
\hline & & & $\begin{array}{l}\text { Wehrens et al., 2000; Schrickel et al., 2002; Li } \\
\text { et al., 2004; Xiao et al., 2004; Saba et al., 2005; } \\
\text { Schrickel et al., 2007; Fabritz et al., 2010; Gros } \\
\text { et al., } 2010\end{array}$ \\
\hline
\end{tabular}

QTc (ms)

398-430 Stein et al., 2002; Rich et al., 2012

Chiamvimonvat et al., 1998; Schauerte

et al., 2001; Dorian et al., 2007;

Roberts-Thomson et al., 2009; Stiles

et al., 2010

Atrial CV $(\mathrm{cm} / \mathrm{s})$

88

Hansson et al., 1998

AV Wenckebach CL (ms)

Chiamvimonvat et al., 1998; Schauerte et al., 2001; Stein et al., 2002; Kose et al., 2004; Dorian et al., 2007; Grecu et al., 2009

Ventricular ERP (ms)

Edvardsson et al., 1984;

Chiamvimonvat et al., 1998; Schauerte et al., 2001; Dorian et al., 2007

30-124 Gehrmann et al., 2000; Maguire et al., 2000; Saba et al., 2000; Schrickel et al., 2002, 2007; Li et al., 2004; Zhang et al., 2005; Sawaya et al., 2007; Stein et al., 2009; Gros et al., 2010

23-71 Thomas et al., 1998; VanderBrink et al., 1999; Verheule et al., 1999; van Veen et al., 2005; Zhang et al., 2005; Sawaya et al., 2007; Schrickel et al., 2007; Li et al., 2009; Odening et al., 2009

30-60 Thomas et al., 1998; Verheule et al., 1999; Alcolea et al., 2004; van Veen et al., 2005

66-133 Thomas et al., 1998; Hagendorff et al., 1999; VanderBrink et al., 1999; Verheule et al., 1999; Maguire et al., 2000; Saba et al., 2000; VanderBrink et al., 2000; Korte et al., 2002; Schrickel et al., 2002; Saba et al., 2005; Zhang et al., 2005; Sawaya et al., 2007; Schrickel et al., 2007; Li et al., 2009; Blana et al., 2010

33-80 Thomas et al., 1998; Verheule et al., 1999; Kovoor et al., 2001; Korte et al., 2002; Saba et al., 2005; van Veen et al., 2005; Zhang et al., 2005; Sawaya et al., 2007; Schrickel et al., 2007; Li et al., 2009; Stein et al., 2009

Ventricular CV $(\mathrm{cm} / \mathrm{s})$

80

de Bakker et al., 1993

$30-60$

Thomas et al., 1998; Morley et al., 1999; Alcolea et al., 2004; van Veen et al., 2005

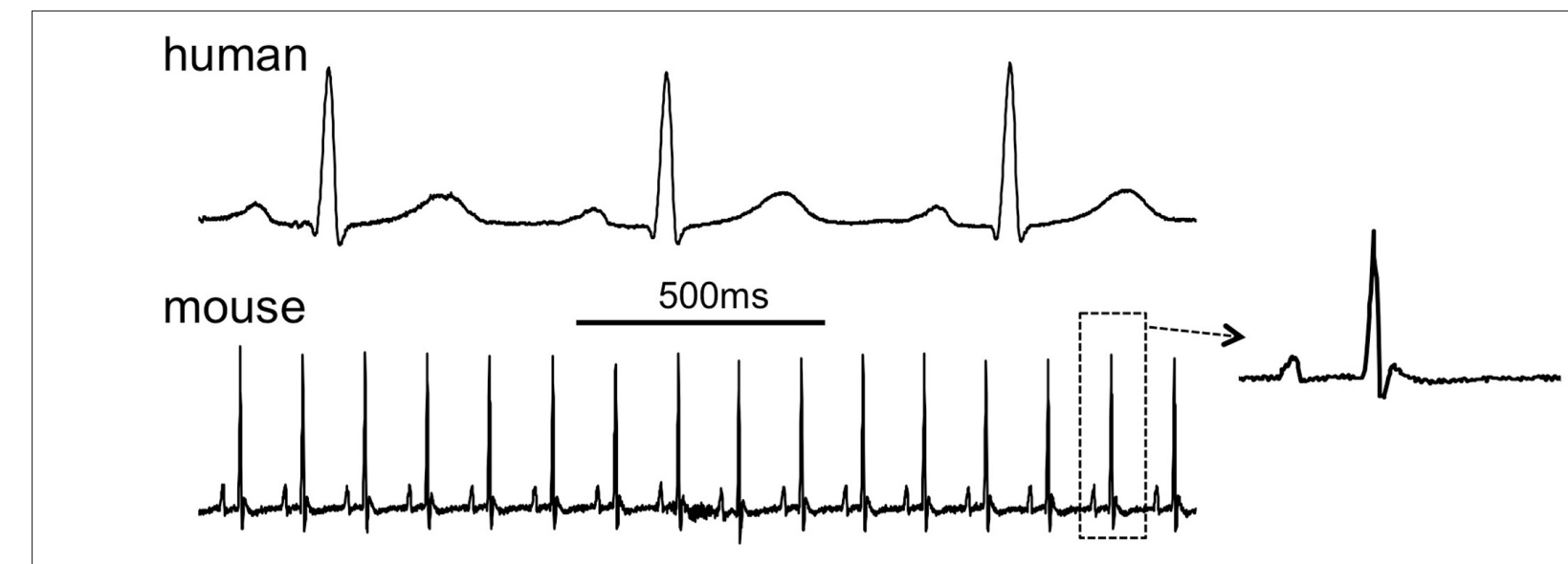

FIGURE 1 | Comparison of the human and murine ECG, 2-s traces showing lead I. Inset shows a single complex from the mouse ECG (human ECG is patient 121 in the PTB database at www.physionet.org, mouse ECG courtesy of Dr. Ricardo Carnicer, Oxford University).

Mice can increase their HR by around 30-40\% (Vornanen, 1992; Kass et al., 1998; Fabritz et al., 2010), whereas humans HR can increase by $300 \%$. Thus, an increase in frequency can contribute far less to increase cardiac output (CO) in mice than in humans. The ratio of maximal to resting heart rate scales to $\mathrm{BM}$ with the following equation $\mathrm{HR}_{\max } / \mathrm{HR}_{\text {rest }}=1.87 \times \mathrm{BM}^{-0.1}$
(Kass et al., 1998). Actin-myosin crossbridge kinetics have an estimated maximal rate of around $1000 \mathrm{bpm}$, corresponding to a cycle length (CL) of $60 \mathrm{~ms}$ (Kass et al., 1998). Maximal heart rates observed in mice are in a range of $725-815 \mathrm{bpm}$ (Vornanen, 1992; Kass et al., 1998; Fabritz et al., 2010). Thus, an increase in murine HR is limited as the maximal HR is close to the maximal 
actin-myosin crossbridge frequency. In addition, studies in mice have found an AV Wenckebach period of 66-103 ms (Table 1). With an increase in HR, this Wenckebach period is reached relatively quickly, also limiting the increase in CO. For efficient cardiac pump function and $\mathrm{CO}$, optimal timing of AV conduction is required. Late diastolic left ventricular filing time scales with heart length and with an 1/3 exponent to cardiac or body mass, whereas AV delay scales with an $1 / 4$ exponent of heart or body mass (Noujaim et al., 2004; Meijler et al., 2005). In mice, an increase in heart rate decreases diastolic left ventricular filing time and thus gradually reduces ventricular end-diastolic volume. Finally, mice at physiological HR have a small force-frequency reserve compared to humans (Georgakopoulos and Kass, 2001). Consequently, ventricular filing is limited at high heart rates in mice, further impeding CO enhancement and cardiac contractility. Taken together, these factors explain why mice can raise their CO only over a small range, whereas humans can increase their $\mathrm{CO}$ by a factor $5-6$. This difference should be taken into account when HR regulation (e.g., during exercise) is relevant.

\section{CARDIAC ACTIVATION IN MICE SINOATRIAL NODE}

The lateral and medial limb of the crista terminalis at the orifice of the superior caval vein frame the murine SA node region (Verheijck et al., 2001; Mommersteeg et al., 2007). During development, the SA is node is distinguished from the adjacent atrial myocardium by the absence of the transcription factor Nkx2.5 and the presence of the transcription factors Tbx3 and Tbx18, both in humans and mice (Christoffels et al., 2006; Mommersteeg et al., 2007; Sizarov et al., 2011). These differences in transcription factor profiles initiate diverging gene expression programs, leading to differences in e.g., connexin and ion channel expression (Hoogaars et al., 2007). Histologically, the SA node consists of a large head and a smaller tail along the crista terminalis (Wiese et al., 2009). Characteristic sinus node APs (a marked diastolic depolarization and low upstroke velocity) are found in a region $300 \mu \mathrm{m}$ in parallel and $150 \mu \mathrm{m}$ perpendicular to the crista terminalis (Opthof, 2001; Verheijck et al., 2001). A morphologically "nodal" cell type is present in a somewhat larger region $500 \mu \mathrm{m}$ parallel to the crista (Opthof, 2001; Verheijck et al., 2001). Surprisingly, Glukhov et al. have shown that in the mouse, the location of the dominant pacemaker can shift during (para)sympathomimetic treatment within a still larger region of approximately $5 \times 2 \mathrm{~mm}$ between the superior and inferior caval veins (Glukhov et al., 2010).

The sinoatrial conduction time, defined as the conduction time from the primary, dominant sinus node cells to atrial myocardium is $4-5 \mathrm{~ms}$ and the transition from a nodal to an atrial AP morphology takes place over a very short distance of about $100 \mu \mathrm{m}$ (Opthof, 2001; Verheijck et al., 2001).

SA nodal APs in mice have an amplitude, maximum diastolic potential and upstroke velocity comparable to those in humans, but a much shorter APD, probably due to differences in delayed rectifier currents (Opthof, 2001). The SCN5A encoded cardiac Nav1.5 sodium channel affects SA node pacemaker function, as heterozygous deletion of the SCN5A gene in mice caused sinus bradycardia and exit block (Lei et al., 2005). Similarly, sinus bradycardia and sinus pauses are prevalent in LQT3 patients with certain SCN5A mutations (Veldkamp et al., 2003). However, SCN5A-related alterations in sinus node function may be caused by the involvement of Nav1.5 in extracellular matrix remodeling, rather than a primary electrical effect (Hao et al., 2011). The $\alpha_{1 D}$ form of the L-type $\mathrm{Ca}^{2+}$ channel is expressed in the SA node and contributes to diastolic depolarization and pacemaker activity, and deletion of this gene leads to sinus bradycardia (Zhang et al., 2002; Mangoni et al., 2003; Qu et al., 2005).

The murine SA node expresses hyperpolarization-activated, nonselective cation channels from the HCN family. HCN4 is the dominant isoform, although smaller amounts of HCN1 and HCN2 are also expressed (Liu et al., 2007; Ludwig et al., 2008; Herrmann et al., 2011). Specific mutations in the HCN4 gene can cause bradycardia in humans (Milanesi et al., 2006). HCN4 knock-out mice have produced diverging results (Herrmann et al., 2012). Mice with conditional ubiquitous HCN4 deletion in the adult stage were not bradycardic, even at less than $10 \%$ of normal HCN4 levels, but did show sinus pauses that were activity dependent and more prevalent at low heart rates (Herrmann et al., 2007; Hoesl et al., 2008). I in isolated SA nodal cells from these mice was decreased by $75 \%$ and these cells often did not show pacemaker activity under baseline conditions, but did become spontaneously active in response to adrenergic stimulation (Herrmann et al., 2007; Ludwig et al., 2008). However, another mouse model with heart-specific conditional deletion of HCN4 did show profound sinus bradycardia (Baruscotti et al., 2011). HCN2 deficient mice have a sinus dysarrhythmia leading to a marked increase in RR variability, although the response to adrenergic and cholinergic stimulation was preserved (Ludwig et al., 2003).

In mice, Cx45 is expressed in SA node center (Opthof, 2001; Verheijck et al., 2001). On the epicardial side, the murine SA node is entered by strands of cells expressing Cx40 and Cx43 (Verheijck et al., 2001). Also in humans, atrial myocardial cells with Cx43 expression protrude into the $\mathrm{Cx} 43$ negative SA nodal area (Oosthoek et al., 1993). The murine SA node architecture containing different types of gap junctions and connective tissue around the nodal area are hypothesized to shield the SA node against hyperpolarizing influence of surrounding atrial myocardium and thus to allow pacemaker activity and conduction from the SA node to atrial myocardium (Verheijck et al., 2001).

\section{ATRIAL ACTIVATION}

Various studies have shown atrial conduction patterns in mice. Atrial activation starts near the expected location of the sinoatrial node close to the superior vena cava and from there spreads rapidly over the right and left atria (Leaf et al., 2008; Mathur et al., 2009; Blana et al., 2010; Kirchhof et al., 2011; Swaminathan et al., 2011). It is not clear whether mice have a true Bachmann's bundle, which in larger species is a thick, highly anisotropic structure consisting of many parallel fibers, serving as the largest and fastest conduction pathway between the atria. The total atrial conduction time amounts to approximately $15 \mathrm{~ms}$ (Blana et al., 2010; Swaminathan et al., 2011). The atria express both $\mathrm{Cx} 40$ and $\mathrm{Cx} 43$. The specific role of $\mathrm{Cx} 40$ is unclear, with observations in $\mathrm{Cx} 40^{-/-}$ 
mice ranging from a reduced CV (Verheule et al., 1999) to a reduced conduction heterogeneity without a change in CV (Leaf et al., 2008). The atrial ERP shows little rate-dependence and in some cases it may be longer than the AV nodal ERP (Etzion et al., 2008).

\section{ATRIOVENTRICULAR NODE}

The murine AV node has similar properties to the human AV node (VanderBrink et al., 1999). In some humans, the AV node shows "dual AV physiology" with a distinct slow and fast pathway, giving rise to a discontinuous AV conduction curve during premature atrial stimulation. The prevalence of dual AV nodal physiology increases during postnatal development and around $40 \%$ of adult humans display dual AV nodal physiology (Denes et al., 1973; Thapar and Gillette, 1979; Cohen et al., 1997). A maturation study in mice demonstrated that dual AV nodal physiology and AV nodal echo beats also become more frequent with increasing age, but without inducibility of AV nodal reentry tachycardia (Maguire et al., 2000). In contrast, another study of the murine AV node did not find dual AV nodal physiology (VanderBrink et al., 1999). As in larger species, the AV node shows "facilitation" during an acceleration in rate, and this property is lost in Cx40 deficient mice (Zhu et al., 2005).

The areas bordering the AV node show a complex profile of $\mathrm{Cx}$ expression, which has been studied in mice and humans (Aanhaanen et al., 2010; Greener et al., 2011). Myocytes in the compact node, the area responsible for the major part of the AV delay, express $\mathrm{Cx} 40$ and $\mathrm{Cx} 45$ in both mice and humans. In addition, Cx30.2 is expressed in mice, but its orthologue Cx31.9 is not present in the human AV node. In $\mathrm{Cx} 40^{+/-}$mice and $\mathrm{Cx} 45^{+/-}$ mice, AV conduction is not affected (Hagendorff et al., 1999; Verheule et al., 1999; Kruger et al., 2006). The AV delay increases in $\mathrm{Cx} 40^{-/-}$mice (Hagendorff et al., 1999; Verheule et al., 1999) and increases further in $\mathrm{Cx} 40^{-/-} \mathrm{Cx} 45^{+/-}$mice (Kruger et al., 2006), indicating that both connexins contribute to AV conduction. Intriguingly, the $\mathrm{AV}$ delay is shorter in $\mathrm{Cx} 30.2^{-/-}$mice and normal in $\mathrm{Cx} 30.2^{-/-} \mathrm{Cx} 40^{-/-}$mice (Kreuzberg et al., 2006; Schrickel et al., 2009). Thus, Cx30.2 may represent an arrangement to decelerate $\mathrm{AV}$ nodal conduction that is specific to mice.

In humans, the homeobox transcription factor Nkx2-5 is expressed in the AV node and heterozygous mutations caused congenital atrioventricular conduction abnormalities, e.g., AV block (Schott et al., 1998). A murine model with a heterozygous Nkx2-5 mutation has a hypoplastic AV node (Jay et al., 2004). Furthermore, overexpression of a human mutation of Nkx2-5 in transgenic mice led to heart failure and progressive AV conduction defects, possibly due to reduced $\mathrm{Cx} 40$ and $\mathrm{Cx} 43$ expression (Kasahara et al., 2001). Similarly, haploinsuffiency in mice of the transcription factor Tbx5, which has a synergystic effect with Nkx2-5 on gene transcription, causes abnormalities similar to those in the human Holt-Oram syndrome, including decreased Cx40 expression and AV block (Bruneau et al., 2001; Moskowitz et al., 2007).

\section{VENTRICULAR ACTIVATION AND REPOLARIZATION}

The ventricular conduction system lineage is established during development by expression of the transcription factors $\mathrm{Nkx} 2-5$ and Tbx5, (Jay et al., 2004; Moskowitz et al., 2007) activating a gene program that includes $\mathrm{Cx} 40$, the major gap junction protein in the His bundle and proximal conduction system. Deletion of $\mathrm{Cx} 40$ leads to conduction slowing in the ventricular conduction system (Simon et al., 1998; Bevilacqua et al., 2000; VanderBrink et al., 2000). The murine left bundle branch is thicker than the right bundle branch, as evidenced by $\mathrm{Cx} 40$ expression patterns (van Rijen et al., 2001). This is supported by studies that suggested that the left bundle brunch contains more parallel fibers and thus probably has a higher conduction reserve than the right bundle branch, possibly explaining why the right bundle branch is more prone to conduction block (Alcolea et al., 2004). Similarly, clinical studies tend to show a higher prevalence of conduction block in the right bundle branch than in the left bundle branch (Tuzcu et al., 1990; Newby et al., 1996; Golshayan et al., 1998).

The activation pattern of ventricular myocardium differs between mice and humans. In mice, on study has reported that ventricular epicardial activation starts with clearly defined breakthroughs in the right ventricle and subsequently in the left ventricle (Tamaddon et al., 2000). Another study has shown a first breakthrough at the left ventricular apex, followed shortly by a right ventricular breakthrough (Nygren et al., 2000). By contrast, studies in humans found first depolarization at the left ventricular side of the interventricular septum, conducted by septal left bundle branch fibers and corresponding to the $\mathrm{Q}$ wave in the ECG (Durrer et al., 1970). Septal right bundle branch fibers cause subsequent right ventricular activation (Durrer et al., 1970). Within the interventricular septum, mice show an activation pattern from base to apex, probably due to an electrical connection from the common bundle into the ventricular septum (van Rijen et al., 2001). By contrast, humans show intraventricular septal activation from left to right and from apex to base (Durrer et al., 1970). Conduction velocity is slower in the midseptal than in the proximal region of the murine bundle branches, due to regional differences in bundle geometry and connexin expression (van Veen et al., 2005). During murine intrauterine development, the epicardial ventricular activation pattern switches from basicoapical to apico-basal, in correspondence with maturation of the conduction system (Rentschler et al., 2001; Gourdie et al., 2003).

Within the mouse ventricles, repolarization is earlier in the epicardium than in the endocardium due to a shorter epicardial action potential (Knollmann et al., 2001), and earlier at the apex than at the base (Killeen et al., 2007b; London et al., 2007). Transmural and apico-basal gradients in $\mathrm{I}_{\text {to }}$ are thought to be the main determinant of heterogeneity of the murine ventricular APD (Rossow et al., 2006; Wang et al., 2006; Killeen et al., 2007b; London et al., 2007).

$\mathrm{Cx} 43$ is the main gap junction protein in the ventricular working myocardium, but its expression can be decreased by $\sim 80 \%$ before a marked decrease in CV and increase in vulnerability to arrhythmias becomes apparent (Danik et al., 2004; van Rijen et al., 2004), as would be expected based on mathematical models (Shaw and Rudy, 1997). However, more modest reductions in gap junctional coupling may have significant effects when they occur in conjunction with other factors such as reduced excitability or fibrosis (van Veen et al., 2005; Stein et al., 2009). Similar conjunctions of disease processes are common in 
human pathology, but poorly represented by monogenic mouse models.

\section{ARRHYTHMIAS LINKED TO ABNORMAL CARDIAC DEVELOPMENT}

Some studies have linked human arrhythmias to gene programs active during prenatal cardiac development. The developing mouse heart contains muscular atrioventricular connections over the annulus fibrosus (Rentschler et al., 2001). Persistence of these connecting fibers bypass the AV node and cause ventricular pre-excitation syndromes similar to Wolff-Parkinson-White syndrome (Rentschler et al., 2001) Patients suffering from WolffParkinson-White syndrome showed mutations in the PRKAG2 gene, which encodes the gamma-2 subunit of the AMP-activated protein kinase (Blair et al., 2001; Gollob et al., 2001). In mice, overexpression of one of the human mutations of the PRKAG2 gene caused ventricular preexcitation and an altered annulus fibrosis structure, disrupted by glycogen-filled myocytes that may function as accessory pathways (Arad et al., 2003). Similarly, inactivation of Tbx2, a transcription factor involved in the development of the atrioventricular canal, leads to malformation of the annulus fibrosis and ventricular preexcitation (Aanhaanen et al., 2011). Mutations in Tbx3 are linked to ulnar-mammary syndrome in humans. In mice, a reduction in Tbx3 activity leads to SA node dysfunction, AV block and ventricular preexcitation (Frank et al., 2012).

Gittenberger-de Groot and co-workers have presented extensive evidence for the relationship between nodal pacemaker tissue and the myocardial sleeves in the developing embryo (Douglas et al., 2011) For example, podoplanin is a myocardial marker expressed in cells of the developing pacemaking system, which later differentiate e.g., to the sinoatrial node (SA node) and atrioventricular node (AV node) (Gittenbergerde Groot et al., 2007). Podoplanin expression is also present in surrounding myocardium of the common pulmonary vein (PV) (Gittenberger-de Groot et al., 2007), an area that can later become important in the genesis of atrial fibrillation in humans (Haissaguerre et al., 1998). These embryological relationships have been proposed account for ectopic activity in the myocardial sleeves of the pulmonary veins (Jongbloed et al., 2004). However, the sinus node originates from a different type of cardiac precursor cells (i.e., Tbx18-positive and Nkx2.5-negative) than the PV myocardium (Christoffels et al., 2006). In addition, a nodal phenotype would be more likely to give rise to relatively slow, gradually appearing and disappearing pacemaking activity, as has been described in guinea pig pulmonary veins (Cheung, 1981). By contrast, human PVs show paroxysms of arrhythmic activity that initiate and terminate suddenly, with very rapid rates that are more compatible with triggered activity or microreentry than with a pacemaking activity in a latent nodal region (Haissaguerre et al., 1998).

\section{CARDIAC CELLULAR ELECTROPHYSIOLOGY}

In general, the duration of cardiac action potentials increases with body size and is approximately $50 \mathrm{~ms}$ in mouse ventricles (Danik et al., 2002), compared to $250 \mathrm{~ms}$ in humans (Edvardsson et al., 1984). The morphology of the action potential reflects the contribution of numerous depolarizing and repolarizing currents. Even when the same type of ion channel is expressed in human and mice, its contribution to the morphology of the action potential may differ substantially, given the large difference in APD. Both in mice and humans, the refractory period ends before complete repolarization of the AP (Knollmann et al., 2001; Fabritz et al., 2003; Sabir et al., 2007a,b). Based on recordings of monophasic action potentials, the ERP in mouse ventricles corresponds to the APD80 (Knollmann et al., 2001).

Murine and human ventricular APs are both characterized by a fast depolarizing phase (phase 0), the AP upstroke, which is generated by the large, rapidly activating sodium current $\mathrm{I}_{\mathrm{Na}}$ (Nerbonne, 2004). The subsequent repolarization phase is a delicate balance of several depolarizing currents $\left(\mathrm{I}_{\mathrm{CaL}}, \mathrm{I}_{\mathrm{NCX}}\right)$ and repolarizing potassium currents. In the human ventricle, a fast repolarizing phase (phase 1) is followed by the action potential plateau (phase 2) (Nerbonne, 2004). In the mouse heart, the L-type $\mathrm{Ca}^{2+}$ current $\left(\mathrm{I}_{\mathrm{CaL}}\right)$ contributes less to the ventricular AP than in humans (Sabir et al., 2008) and therefore the murine AP shows a gradual repolarization rather than a distinct plateau phase. In the mouse ventricles, $\alpha_{1 C}$ channels are primarily responsible for $\mathrm{I}_{\mathrm{CaL}}$. By contrast, the $\mathrm{I}_{\mathrm{CaL}}$ of supraventricular myocardium consists of both $\alpha_{1 \mathrm{C}}$ and $\alpha_{1 \mathrm{D}} \mathrm{Ca}^{2+}$ channels (Zhang et al., 2005; Mancarella et al., 2008; Zhang et al., 2011). The $\alpha_{1 \mathrm{D}}$ $\mathrm{Ca}^{2+}$ channel makes a significant contribution to $\mathrm{Ca}^{2+}$ influx and $\mathrm{Ca}^{2+}$ induced $\mathrm{Ca}^{2+}$ release from the SR in atrial myocytes (Mancarella et al., 2008).

In humans, the plateau phase ends when the balance shifts from $\mathrm{I}_{\mathrm{NCX}}$ and the slowly inactivating $\mathrm{I}_{\mathrm{CaL}}$ to slowly activating potassium currents, giving rise to the final repolarization (phase 3) until the resting potential (phase 4) is restored. In the human ventricle, the rapid and slow delayed outward rectifier $\mathrm{K}^{+}$ currents $\left(\mathrm{I}_{\mathrm{Kr}}\right.$ and $\mathrm{I}_{\mathrm{Ks}}$ ) are predominantly responsible for phase 3 repolarization (Li et al., 1996). In contrast, the much faster repolarization in mice ventricles is mediated by transient outward $\mathrm{K}^{+}$ currents with a fast and slow recovery from inactivation $\left(\mathrm{I}_{\mathrm{to}, \mathrm{f}}\right.$ and $\left.\mathrm{I}_{\mathrm{to}, \mathrm{s}}\right)$, a slowly inactivating $\mathrm{K}^{+}$current $\left(\mathrm{I}_{\mathrm{K}, \text { slow1 }}\right.$ and $\left.\mathrm{I}_{\mathrm{K} \text {,slow2 } 2}\right)$ and a non-inactivating, steady state current $\left(\mathrm{I}_{\mathrm{ss}}\right.$ ) (Guo et al., 1999; Xu et al., 1999; Zhou et al., 2003; Brouillette et al., 2004; Sabir et al., 2008). In humans, the $I_{\text {to.f }}$ current is mainly involved in phase 1 repolarization, with more prominent expression in the epicardium (Nerbonne, 2004). In mice, $\mathrm{I}_{\mathrm{to}, \mathrm{f}}$ is expressed throughout the left and right ventricles, whereas $\mathrm{I}_{\mathrm{to}, \mathrm{s}}$ is confined to the septal myocardium (Xu et al., 1999). The equivalents of murine $I_{s s}$ and $\mathrm{I}_{\text {Kslow }}$ have not been detected in human ventricles (Sabir et al., 2008). Studies in mice did observe the rapid and slow delayed rectifier $\mathrm{K}^{+}$currents $\left(\mathrm{I}_{\mathrm{Kr}}\right.$ and $\mathrm{I}_{\mathrm{Ks}}$ ), but their contribution to repolarization under physiological conditions is probably negligible or minor (Babij et al., 1998; Drici et al., 1998; Balasubramaniam et al., 2003; Nerbonne, 2004; Salama et al., 2009). In the ventricles of mice and humans, the inwardly rectifying $\mathrm{K}^{+}$channel $\left(\mathrm{I}_{\mathrm{K} 1}\right)$ plays a similar role in stabilizing the resting membrane potential and determining terminal repolarization (Babenko et al., 1998; Flagg and Nichols, 2001; Lopatin and Nichols, 2001; Nerbonne et al., 2001; Nerbonne, 2004). During postnatal development, the APD shortens progressively as a result of the upregulation of a number of potassium currents, both in the atria (TrepanierBoulay et al., 2004) and in the ventricles (Grandy et al., 2007). 
In the adult mouse heart, atrial and ventricular action potentials are very similar in morphology [for a detailed review of all underlying currents see Nerbonne (2004)].

Genetically engineered mice have revealed surprising contributors to the cardiac action potential. For example, deletion of the calcium-activated potassium channel SK2 prolongs the APD in atrial myocytes and leads to AF (Li et al., 2009), although SK channels do not seem to contribute to the normal atrial action potential in larger species (Nagy et al., 2009). SK channel function may be affected by the tendency of SK subunits to form heteromers (Tuteja et al., 2010), and its functional contribution may increase under pathological conditions, also in the ventricular myocardium (Chua et al., 2011). In the mouse ventricles, deletion of the "pacemaker current" HCN3 leads to an increase in T wave amplitude due to an acceleration of the terminal repolarization in epicardial myocytes (Fenske et al., 2011).

The main $\mathrm{Ca}^{2+}$ extrusion mechanism in cardiomyocytes is the $\mathrm{Na}^{+} / \mathrm{Ca}^{2+}$ exchanger (NCX), which generates a net depolarizing current due to its stoichiometry (Bers, 2002; Pott et al., 2004). In most respects, mice overexpressing NCX and cardiac-specific NCX knockouts show opposite cardiac phenotypes, although cardiac hypertrophy was observed in both (Henderson et al., 2004; Pott et al., 2004; Goldhaber et al., 2005; Reuter et al., 2005; Pott et al., 2012). Due to the calcium-dependence of $\mathrm{I}_{\mathrm{CaL}}$ inactivation, NCX overexpressing mice and cardiac-specific NCX knockouts had accelerated and decelerated inactivation kinetics of $\mathrm{I}_{\mathrm{CaL}}$, respectively, leading to APD prolongation and shortening, respectively (Pott et al., 2004; Goldhaber et al., 2005; Reuter et al., 2005; Pott et al., 2007). NCX overexpression increased and cardiac-specific NCX deletion decreased vulnerability to ischemia/reperfusion injury, supporting the role of calcium influx through the reverse-mode NCX under these circumstances (Pott et al., 2004; Imahashi et al., 2005). In hearts of larger mammals, like dog, rabbit, and human, reuptake into the sarcoplasmic reticulum and elimination by the NCX account for approx. $70 \%$ and $30 \%$ of $\mathrm{Ca}^{2+}$ removal, respectively, while in mice and rats up to $90 \%$ of $\mathrm{Ca}^{2+}$ is taken back up into the sarcoplasmic reticulum (Bassani et al., 1994; Nishimaru et al., 2001). Under steady state conditions (i.e., a stable diastolic SR calcium load), the amount of calcium extruded by the sodium-calcium exchanger (NCX) equals the amount of calcium entering through L-type calcium channels. Increased NCX expression is thought to contribute to arrhythmogenesis in failing human and rabbit hearts (Studer et al., 1994; Lindner et al., 1998; Pieske et al., 1999; Pogwizd et al., 1999, 2001; Schillinger et al., 2000), and EADs, DADs and episodes of ventricular tachycardia were inducible in NCXoverexpressing mice (Pott et al., 2012). Increased NCX expression causes reduced twitch calcium transients and SR calcium load in rabbit ventricles (Ranu et al., 2002). In contrast, increased NCX expression in mice does not affect twitch $\mathrm{Ca}^{2+}$ transients and SR calcium load (Adachi-Akahane et al., 1997; Terracciano et al., 1998; Yao et al., 1998). This difference between mice and larger mammals may be caused by a higher cytoplasmic sodium concentration $\left([\mathrm{Na}]_{\mathrm{i}}\right]$ in murine myocytes (Shattock and Bers, 1989; Yao et al., 1998; Despa et al., 2002), which would impair extrusion via NCX (Bers, 2002). A negative force-frequency relationship has been reported for murine ventricles, often with high $\mathrm{Ca}^{2+}$ concentration of the SR, even under low stimulation frequencies (Bers, 2002). Again, the high $[\mathrm{Na}]_{\mathrm{i}}$ may impair $\mathrm{Ca}^{2+}$ extrusion via NCX and explain why an increasing in heart rate hardly affects SR calcium load in mice (Shattock and Bers, 1989; Yao et al., 1998). In addition, refractoriness of excitation contraction coupling and smaller fractional SR $\mathrm{Ca}^{2+}$ is observed during high heart rates (Bers et al., 1993). Both mechanisms probably contribute to negative force-frequency relationship in mouse ventricular myocytes (Bers, 2002).

\section{CHANGES IN CARDIAC ELECTROPHYSIOLOGY IN MOUSE MODELS OF HEART DISEASE MYOCARDIAL INFARCTION}

Mouse models of myocardial ischemia and infarction are commonly generated by ligation of the left anterior descending coronary artery (LAD). Temporary ligation of the LAD with subsequent reperfusion has been used as a model of ischemiareperfusion injury, allowing determination of the infarct size in relation to the area at risk (Michael et al., 1995). In Langendorff-perfused mouse hearts, regional ischemia and reperfusion increased the incidence of induced and spontaneous ventricular tachycardia (VT) (Koyama et al., 2003; Inagaki et al., 2005; Anzawa et al., 2006; Maass et al., 2009; He et al., 2012). Depending on the exact inschemia-reperfusion protocol, ventricular fibrillation (VF) may also be observed (Koyama et al., 2003; Inagaki et al., 2005; He et al., 2012), especially when catecholamines are added to the perfusate (Stables and Curtis, 2009). In open-chest experiments, episodes of ventricular tachycardia (VT) were observed both during regional ischemia and reperfusion (Sakamoto et al., 1999; Anyukhovsky et al., 2011). Mice with a permanent ligation of the LAD show infarct-related changes in T-wave morphology, reduced cardiac function, and increased inducibility of atrial and ventricular arrhythmias (Gehrmann et al., 2001). In conscious mice with a myocardial infarction (MI), telemetric monitoring revealed frequent premature ventricular beats, but spontaneous VT episodes were rare (Betsuyaku et al., 2004). Heart rate variability (HRV) a marker of autonomic nervous system activity and a predictor of arrhythmias in human MI patients, was not affected by MI in mice (Gehrmann et al., 2001) Decreased HRV is thought to result from an enhanced sympathetic and decreased parasympathetic activity, but in contrast to humans, mice already show a predominant sympathetic tone, since parasympathetic blockade does not increase in HR (Mansier et al., 1996; Wickman et al., 1998) but sympathetic blockade caused a pronounced decrease in HR (Janssen et al., 2000; Just et al., 2000). For a detailed review on autonomic regulation of cardiac function in mice, see (Janssen and Smits, 2002).

\section{PRESSURE OVERLOAD}

Transverse aortic constriction (TAC) by banding the proximal aorta has become a standard method to generate chronic pressure overload in mice, leading to LV hypertrophy with decreased fractional shortening within 4-5 weeks (Hill et al., 2000). TAC leads to an increase in QRS duration and a decrease in RV longitudinal conduction velocity (Boulaksil et al., 2010). Furthermore, these mice showed increased interstitial fibrosis and $\mathrm{C} \times 43$ heterogeneity (Boulaksil et al., 2010), and an increased inducibility 
of polymorphic ventricular tachyarrhythmias (Boulaksil et al., 2010; Jansen et al., 2012; Vinet et al., 2012). The inducibility and stability of atrial fibrillation also increase as a result of TAC (Liao et al., 2010). In addition to the working myocardium, pressure overload may also affect $\mathrm{Cx}$ and HCN expression in the ventricular conduction system and thereby alter the ventricular activation pattern (Harris et al., 2012).

\section{METHODS FOR STUDYING MURINE CARDIAC ELECTROPHYSIOLOGY}

Different mouse strains show considerable differences in baseline electrocardiographic parameters (Wehrens et al., 2000; Waldeyer et al., 2009) and in processes such as for example wound healing after myocardial infarction (van den Borne et al., 2009), underscoring the importance of a homogeneous genetic background in assessing the role of a genetically modified gene. Studying murine cardiac physiology has required the miniaturization of instruments and techniques originally developed for human studies. This section will briefly outline a number of techniques that are currently available.

\section{SURFACE ELECTROCARDIOGRAMS}

As shown in Figure 1, murine and human ECGs show some salient differences that complicate comparison of ECGs from both species (Sabir et al., 2008). In both species, the ECGs show $\mathrm{P}$ waves, reflecting spread of atrial depolarization (Sabir et al., 2008). Subsequently, both ECGs show an isoelectric PQ interval that reflects impulse conduction from the atria through the AV node and the His-Purkinje system to the ventricles (Schrickel et al., 2002; Sabir et al., 2008). In mice and humans, the ensuing QRS complex reflects ventricular depolarization (Schrickel et al., 2002; Sabir et al., 2008). The normal murine ECG shows a distinct $J$ wave at the end of the QRS complex (Liu et al., 2004). By contrast, the human ECG infrequently displays a slight J wave, but it can become more prominent during hypothermia (Osborn, 1953). Because of the triangular shape of the murine ventricular action potential, with a gradual time course of repolarization, mouse ventricles do not have a distinct "moment of repolarization." As a result, the T wave in the murine ECG is often poorly visible (Liu et al., 2004; Sabir et al., 2008). In some murine studies, the QT interval was defined as the period between the start of the $\mathrm{Q}$ wave to the point of return to the isoelectrical line (Verheule et al., 1999; Schrickel et al., 2002). However, correlation of monophasic action potential recordings with the surface ECG indicates that the terminal repolarization of the ventricles may extend into the subsequent P-wave (Danik et al., 2002; Liu et al., 2004). The absence of a clear $\mathrm{T}$ wave impedes investigation of murine ventricular repolarization in the surface ECG (Danik et al., 2002). Within the physiological range, the relative degree of rate dependence of the ventricular APD is comparable between mice and humans (Knollmann et al., 2007). The murine QT interval can be corrected for heart rate using Bazett's formula, which is used in human ECG analysis, or (preferably) by a related formula specifically modified for mice (Mitchell et al., 1998).

Small implantable ECG transmitters permit investigation of spontaneous arrhythmias in conscious mice during normal physical activity and during short-term and long-term drug application (Gehrmann and Berul, 2000; Gehrmann et al., 2000; Fabritz et al., 2010). This technique also allows investigation of acute and chronic exercise stress on arrhythmogenesis by using standardized protocols such as e.g., swimming exercise (Berul, 2003; Fabritz et al., 2010). In determining the degree of exercise, it should be take into account that mice will voluntary run a respectable distance of $6 \mathrm{~km}$ per day (de Waard et al., 2007).

\section{PROGRAMMED ELECTRICAL STIMULATION IN INTACT MICE}

In intact mice under anaesthesia, transesophageal catheters can be used for programmed electrical stimulation of the atria for arrhythmia induction and determination of sinus node recovery time, AV nodal ERP and Wenckebach period (Schrickel et al., 2002; Berul, 2003; Verheule et al., 2004). Due to the lack of direct contact with the atrium and the distance between stimulation poles, stimulus artefacts during transesophageal stimulation are large, obscuring the atrial complex. Therefore, the atrial ERP can not be determined reliably using this technique (Etzion et al., 2008). Because transesophageal stimulation allows survival of the animal, it can be used for longitudinal studies of cardiac electrophysiology over a longer time period. The ventricles cannot be paced using transesophageal stimulation, but Gutstein et al. have presented a method for subdiaphragmatic ventricular stimulation that allows repeated studies in individual mice (Gutstein et al., 2003).

Pacing (and recording) electrodes can be attached either epicardially in open chest experiments (Berul et al., 1996; Verheule et al., 1999) or endocardially using a transvenous access route (VanderBrink et al., 1999; Saba et al., 2000). The latter also permits the recording of his bundle potentials (VanderBrink et al., 1999; Saba et al., 2000). Programmed electrical stimulation using epi- or endocardial electrodes allows assessment of SA node and AV node function, refractory periods, Wenckebach periodicities and vulnerability to atrial and ventricular arrhythmias (Gehrmann et al., 2000; Saba et al., 2000; Berul, 2003). Given the small dimensions of the mouse heart, close apposition of the poles of the stimulation electrode is necessary to reduce stimulus artefacts and allow recording of local electrograms (Verheule et al., 1999; Etzion et al., 2008).

\section{MAPPING IN PERFUSED MOUSE HEARTS}

Isolated Langendorff perfused hearts allow detailed studies of cardiac electrophysiology without neurohumoral and autonomic influences, under artificial conditions that can easily be manipulated. Perfused hearts allow pacing and recording of electrograms and monophasic action potentials (Fabritz et al., 2003; Blana et al., 2010). In addition, the Langendorff setup offers the opportunity to perform high-density epicardial mapping using multi-electrode arrays to record activation patterns (van Rijen et al., 2001; Verheule et al., 2004). Sampling frequency has to be sufficiently high in mapping experiments. For example, with a relatively simple $5 \times 5$ electrode array covering $2 \times 2 \mathrm{~mm}$ (about the size of an atrial free wall), the inter-electrode distance would be $0.4 \mathrm{~mm}$. Assuming a conduction velocity of $0.5 \mathrm{~m} / \mathrm{s}$, (Verheule et al., 1999, 2004) the time difference between electrodes in the 
propagation direction would be $0.8 \mathrm{~ms}$. Accurate determination of local conduction velocities would then require a sampling frequency of at least $2.5 \mathrm{kHz}(1 / 0.8 \times 2)$.

With currently available technology, the highest spatiotemporal resolution can be attained using optical mapping (up to $100 \times 100$ pixels at a sampling rate of up to $10 \mathrm{kHz}$ ). Using this technique, detailed activation mapping has been reported in various mouse models (de Diego et al., 2008; Blana et al., 2010; Lang et al., 2011). In addition, the acquired optical signals are linearly dependent on the transmembrane potential and therefore represent an "ensemble action potential," providing information on the time course of repolarization and diastolic intervals. Furthermore, activation patterns during arrhythmias, e.g., rapid reentry, can be studied in detail (Vaidya et al., 1999; Baudenbacher et al., 2008). However, to suppress motion artefacts, most studies have used excitation-contraction uncouplers such as butadione monoxime, cytochalasin D or blebbistatin, all of which can affect cardiac electrophysiology in mice. 2,3-Butadione monoxime (BDM) markedly shortens the APD (Biermann et al., 1998). In mice, Cytochalasin D prolongs APD and reduces CV (Baker et al., 2004). Blebbistatin has little effect on the AP morphology, (Fedorov et al., 2007) but can suppress arrhythmias by inhibiting myofilament calcium sensitivity (Baudenbacher et al., 2008).

\section{THE ISSUE OF CARDIAC SIZE IN TACHY-ARRYTHMIAS}

In 1914, Garrey postulated that a certain size of myocardial tissue, a "critical mass," is required to sustain reentrant arrhythmias (Garrey, 1924). This led to the belief that the mouse heart would be "too small to fibrillate." This belief has been challenged by murine studies showing atrial (Schrickel et al., 2002; Verheule et al., 2004) and ventricular fibrillation (Vaidya et al., 1999). Specific mouse models of atrial (Nattel et al., 2005; Schotten et al., 2011) and ventricular (Sabir et al., 2008) arrhythmias have been expertly reviewed elsewhere. Similarly, the general mechanisms of atrial (Nattel et al., 2005; Schotten et al., 2011) and ventricular (Antzelevitch, 2001) arrhythmias have been reviewed extensively. Instead, this last section will discuss the general issue of cardiac size in the context of arrhythmias. With respect to the propagation pattern, arrhythmias can be either "hierarchical," with one or more localized sources driving the arrhythmia or "anarchical" where no particular site is driving the arrhythmia. Whereas the former is amenable to targeted ablation strategies, the latter is not. With respect to the underlying mechanism, an arrhythmia will be based on cellular proarrhythmic events giving rise to premature, ectopic action potentials or on reentrant conduction (Antzelevitch, 2001; Sabir et al., 2008). Regardless of the system of classifying arrhythmias, in all cases the size of the substrate is likely to affect the initiation, stability and pattern of the arrhythmia, as discussed below.

\section{REENTRY}

The simplest form of reentry is a single reentrant wave circling around an anatomic obstacle or area of functional block. The "wavelength" of such a wave is the product of CV and ERP. (Wiener and Rosenblueth, 1946) With the normal CV and ERP in the mouse heart, this wavelength (WL) would be approximately

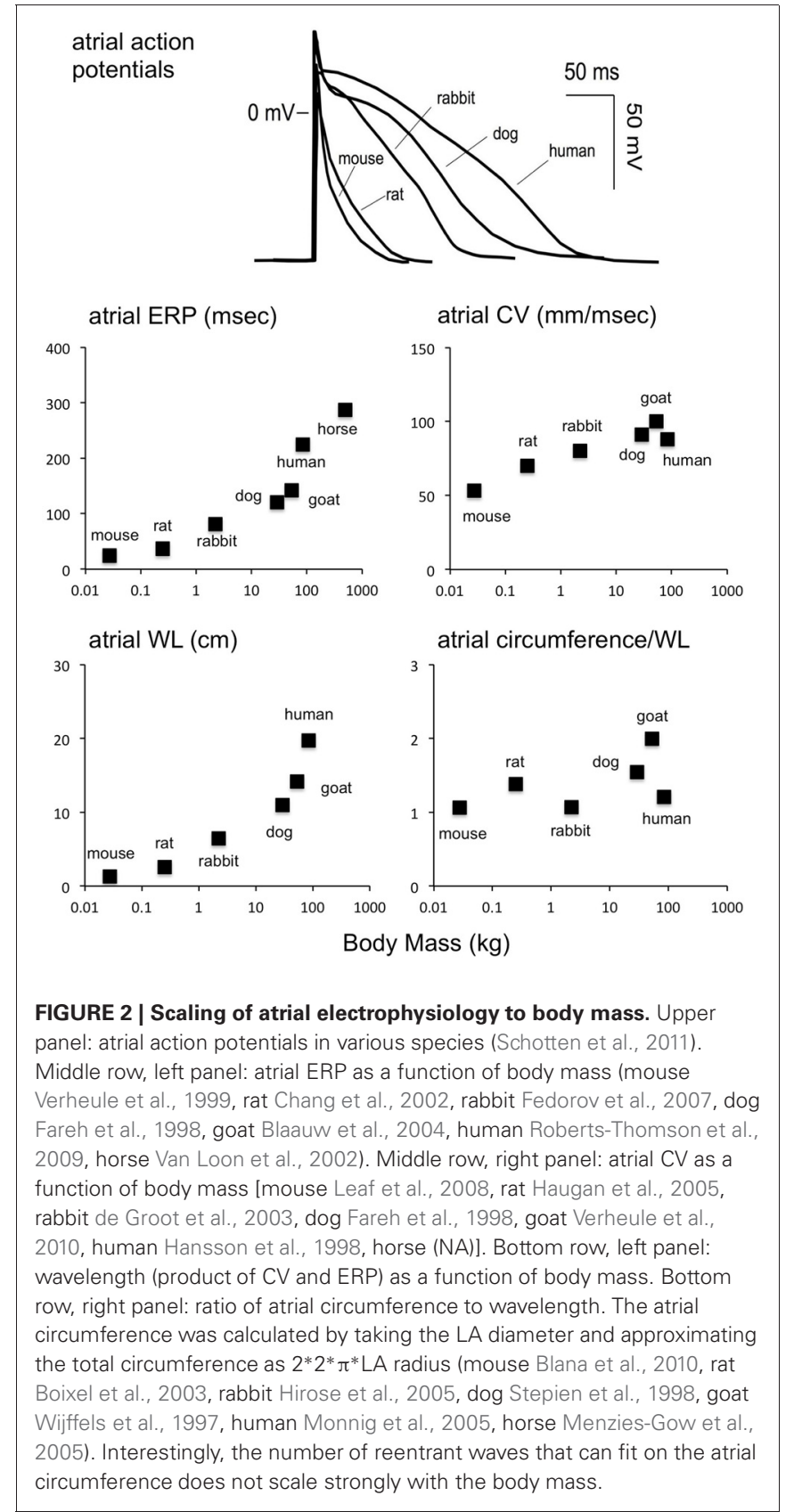

$1.2 \mathrm{~cm}$ in for the atrium, close to the normal estimated atrial circumference (Figure 2). However, this same argument holds true for larger species, as the ratio between estimated atrial circumference to WL is almost completely independent of body mass (Figure 2). According to the WL theory, a decrease in CV or ERP would make reentry more likely. Indeed, shortening the ERP by applying acetylcholine increases AF stability in mice, as it does in larger species (Kovoor et al., 2001; Wakimoto et al., 2001).

A shorter WL would also allow more fibrillation waves to propagate simultaneously within the atria or ventricles. According to the "multiple wavelet theory," fibrillation can persist without any particular site or circuit dominating the arrhythmia, as 
long as a sufficiently large number of irregularly propagating fibrillation waves can coexist within a substrate (Allessie, 1998). The likelihood of multiple wavelet reentry increases when WL becomes smaller (Rensma et al., 1988; Allessie et al., 1996). However, several studies have shown that structural inhomogeneities can lead to "zig-zag" conduction, allowing "microreentry" to occur in much smaller circuits than would be expected based on calculation of the macroscopically determined WL (de Bakker et al., 1993; Spach and Josephson, 1994; Koura et al., 2002). To date, there is no direct evidence that "anarchical" multiple wavelet reentry can occur in mouse hearts. The small substrate size represented by the mouse heart may limit the number of coexisting fibrillation waves and thus make multiple wavelet reentry less likely. For example, the degree of fibrosis necessary to create a substrate for multiple wavelet reentry in a mouse heart may have to be larger than that required in a larger heart. AF stability was indeed greatly increased in a mouse model of selective atrial fibrosis (Verheule et al., 2004), but fibrillatory conduction in this model may be based on triggered activity rather than multiple wavelet reentry (Choi et al., 2012).

Spiral wave reentry is a specific form of reentry that has been described mathematically and observed experimentally in several types of excitable media (Jalife et al., 2002; Comtois et al., 2005). Vaidya et al. demonstrated sustained spiral wave reentry around a single core in murine ventricles with a period of wavefront rotation of $72 \mathrm{~ms}$ and frequency of $14 \mathrm{~Hz}$ (Vaidya et al., 1999). This study also detected figure-of- 8 reentry with a rotation period of $66 \mathrm{~ms}$, demonstrating that the murine ventricle is able to sustain two stable reentrant waves (Vaidya et al., 1999). It is important to note that calculated wavelengths in this study were much larger than size of the mouse heart and that APD showed almost no frequency dependence (Vaidya et al., 1999). Computer simulations suggested that the core during vortex reentry altered repolarization in adjacent myocardium, leading to reduced APDs near the core and longer APDs at larger distance to the core (Beaumont et al., 1998). This hypothesis was supported by the observation that during occurrence of spiral wave reentry, the average APD of the entire preparation was reduced and that pacing at the frequency of the spiral wave produced longer APDs (Vaidya et al., 1999). Thus, wavelength calculations based on external electrical stimulation probably have a poor predictive value for generation and maintenance of spiral wave reentry in the murine heart (Vaidya et al., 1999).

Studies in mammalian species from mouse to horse show scaling of VF frequency with $\mathrm{BM}$, following the equation $\mathrm{VF}_{\text {frequency }}=18.9 \times \mathrm{BM}^{-1 / 4}$ (Noujaim et al., 2007). Noujaim et al. demonstrated stable VF with vortex-like reentry and highest dominant frequency (DF) in the mouse heart with $38 \mathrm{~Hz}$ and reduction of DF with growing BM, as reflected by a DF of $6.8 \mathrm{~Hz}$ in the human heart (Noujaim et al., 2007). However, in larger mammalian hearts, the rapid activity of a rotor in one region does not conduct in a 1:1 fashion to the rest of the substrate. In most cases, and certainly within the complex anatomy of the atria, the waves emanating from that "mother" rotor will break up and spin off "daughter" wavelets to the rest of the atrium (Chen et al., 2000). Thus, the overall conduction pattern will be characterized by interaction of the rotor and fibrillatory waves in the rest of the substrate. When a rotor is present in a relatively small medium, the interaction between the rotor and the rest of the substrate is therefore likely to be different (Zou et al., 2005).

\section{ECTOPIC ACTIVITY}

Cellular proarrhythmic events can give rise to ectopic activity. Accelerated diastolic depolarization of myocytes with pacemaker activity can cause a latent pacemaker region to act as an ectopic focus (enhanced automaticity). By contrast, triggered activity results from "afterdepolarizations" triggered by a normal action potential. Early afterdepolarizations (EADs) develop during phase $2-3$ of the AP and are precipitated by a prolonged APD during which the L-type $\mathrm{Ca}^{2+}$ channels recover and switch from the inactivated to the open state to produce a depolarizing current (Sabir et al., 2008). Delayed afterdepolarizations (DADs) occur during phase 4 of the AP in situations of intracellular $\mathrm{Ca}^{2+}$ overload, evoked by e.g., beta-adrenergic stimulation, ischemia, and hypokalaemia. In this case, the excess of intracellular $\mathrm{Ca}^{2+}$ is transported by the NCX, causing a depolarizing current (Schotten et al., 2011). As discussed in section III, to function at high heart rates, mouse myocytes have a short action potential and some differences in calcium handling compared to myocytes from larger mammalian hearts, and these factors may affect the generation of EADs and DADs. Nevertheless, several mouse models have shown arrhythmias initiated by afterdepolarizations (see e.g., Fabritz et al., 2003; Killeen et al., 2007a; Choi et al., 2012; Li et al., 2012; Pott et al., 2012).

Regardless of its exact nature (diastolic depolarization, early or delayed after depolarization), a proarrhythmic mechanism active in a single myocyte is unlikely to lead to a propagated response in the intact tissue, because the current generated by that myocyte will leak away to its neighbors without reaching the action potential threshold. Thus, the occurrence of a proarrhythmic event will have to be synchronized in a sufficiently large group of myocytes in order to reach the threshold and be able to propagate away from that area. This holds true both for an ectopic pacemaker region (Joyner et al., 2000) and for an area displaying triggered activity (Sato et al., 2009). Does an ectopic focus in a mouse heart have to same relative size to the rest of the heart as a focus in larger mammals? Mouse ventricular myocytes (90 $\mu \mathrm{m}$ in length, $14 \mu \mathrm{m}$ in diameter) (Toischer et al., 2010) are smaller than dog myocytes (130 $\mu \mathrm{m}$ in length, $30 \mu \mathrm{m}$ in diameter) (Clemo et al., 1998). Assuming myocytes to be roughly cylindrical, this would translate to a ratio of 8:1 in myocyte volume between dogs and mice. While considerable, this ratio is much smaller than the 1100:1 ratio in ventricular weight (or volume) between these species (Bienvenu and Drolet, 1991), implying that the mouse ventricle contains far fewer myocytes (by about a factor 150 in this crude estimate). No direct measurements of electrotonic interactions in mouse ventricles are available, but at $0.6 \mathrm{~m} / \mathrm{s}$, the conduction velocity in mouse ventricles is close to that in larger species, suggesting that electrotonic interactions are comparable (Gutstein et al., 2001). These indirect arguments would indicate that an ectopic focus in mouse ventricles may not be much smaller than that in larger hearts, and would thus occupy a relatively larger area of the heart. During rapid focal activity, this size-relation would affect the pattern of fibrillation (i.e., wavebreak). In addition, the small size of the mouse heart would limit the number of localized arrhythmogenic sources that can coexist. Propagation from an ectopic 
focus is most likely when electrical coupling gradually increases from the focus to the surrounding muscle, because a high degree of electrical coupling would effectively silence the focus (Joyner et al., 2007). Thus, structural remodeling (e.g., fibrosis) would allow a smaller focus to successfully conduct its rapid rate to the rest of the heart.

Apart from the role of cardiac size, various other caveats apply to extrapolation of arrhythmias in mouse models to clinically observed human arrhythmias. A very high degree of overexpression or underexpression of a particular gene may lead to indirect alterations that would not be observed as a result of more moderately altered expression of that gene in human pathology. In addition, overexpression or deletion of a gene during the prenatal period may lead to a disruption of cardiac development and result in secondary changes that do not reflect the role of that gene in the adult human heart. All cautionary considerations notwithstanding, mouse models have displayed numerous types of arrhythmias that bear a striking electrocardiographic resemblance to human arrhythmias. These include various tachyarrhythmias such as atrial flutter (Zhang et al., 2005), atrial fibrillation (Verheule et al., 2004), (polymorphic) ventricular tachycardia (Fabritz et al., 2003; van Rijen et al., 2004; Cerrone et al., 2007) and ventricular fibrillation (Cerrone et al., 2005),

\section{REFERENCES}

Aanhaanen, W. T., Boukens, B. J., Sizarov, A., Wakker, V., de Gierde Vries, C., van Ginneken, A. C., Moorman, A. F., Coronel, R., and Christoffels, V. M. (2011). Defective tbx2-dependent patterning of the atrioventricular canal myocardium causes accessory pathway formation in mice. J. Clin. Invest. 121, 534-544.

Aanhaanen, W. T., Mommersteeg, M. T., Norden, J., Wakker, V., de Gier-de Vries, C., Anderson, R. H., Kispert, A., Moorman, A. F., and Christoffels, V. M. (2010). Developmental origin, growth, and three-dimensional architecture of the atrioventricular conduction axis of the mouse heart. Circ. Res. 107, 728-736.

Adachi-Akahane, S., Lu, L., Li, Z., Frank, J. S., Philipson, K. D., and Morad, M. (1997). Calcium signaling in transgenic mice overexpressing cardiac $\mathrm{na}(+)-\mathrm{ca}^{2+}$ exchanger. J. Gen. Physiol. 109, 717-729.

Alcolea, S., Jarry-Guichard, T., de Bakker, J., Gonzalez, D., Lamers, W., Coppen, S., Barrio, L., Jongsma, H., Gros, D., and van Rijen, H. (2004). Replacement of connexin 40 by connexin45 in the mouse: impact on cardiac electrical conduction. Circ. Res. 94, 100-109.

Allessie, M. A., Konings, K., Kirchhof, C. J., and Wijffels, M. (1996). Electrophysiologic mechanisms of perpetuation of atrial fibrillation. Am. J. Cardiol. 77, 10A-23A.
Allessie, M. A. (1998). Atrial electrophysiologic remodeling: another vicious circle? J. Cardiovasc. Electrophysiol. 9, 1378-1393.

Antzelevitch, C. (2001). Basic mechanisms of reentrant arrhythmias. Curr. Opin. Cardiol. 16, 1-7.

Anyukhovsky, E. P., Sosunov, E. A., Kryukova, Y. N., Prestia, K., Ozgen, N., Rivaud, M., Cohen, I. S., Robinson, R. B., and Rosen, M. R. (2011). Expression of skeletal muscle sodium channel (nav1.4) or connexin32 prevents reperfusion arrhythmias in murine heart. Cardiovasc. Res. 89, 41-50.

Anzawa, R., Bernard, M., Tamareille, S., Baetz, D., Confort-Gouny, S., Gascard, J. P., Cozzone, P., and Feuvray, D. (2006). Intracellular sodium increase and susceptibility to ischaemia in hearts from type 2 diabetic $\mathrm{db} / \mathrm{db}$ mice. Diabetologia 49, 598-606.

Arad, M., Moskowitz, I. P., Patel, V. V., Ahmad, F., Perez-Atayde, A. R., Sawyer, D. B., Walter, M., Li, G. H., Burgon, P. G., Maguire, C. T., Stapleton, D., Schmitt, J. P., Guo, X. X., Pizard, A., Kupershmidt, S., Roden, D. M., Berul, C. I., Seidman, C. E., and Seidman, J. G. (2003). Transgenic mice overexpressing mutant prkag2 define the cause of wolff-parkinson-white syndrome in glycogen storage cardiomyopathy. Circulation 107, 2850-2856.

Babenko, A. P., Aguilar-Bryan, L., and Bryan, J. (1998). A view of

bradyarrhythmias such as sinus bradycardia (Lei et al., 2005) and conduction disorders such as AV block (Zhang et al., 2011), bundle branch block (van Rijen et al., 2001), accessory atrioventricular pathways (Arad et al., 2003) and long QT (Salama and London, 2007; Ruan et al., 2009; Sanguinetti, 2010) and Brugada (Martin et al., 2010) syndromes.

\section{CONCLUSIONS}

Over the last two decades, mice have become a widely used model instrument in research into cardiac arrhythmias. Progress in miniaturization of techniques has allowed detailed studies of electrophysiological parameters of the murine heart. Genetic engineering has allowed the generation of mouse models carrying human mutations that cause arrhythmias and has contributed to understanding the role of specific genes, proteins and ionic channels in arrhythmogenesis. In general, mouse models have broadened our knowledge of cardiac electrophysiology and mechanisms underlying atrial and ventricular arrhythmias in humans. Mouse models can mimic human cardiac arrhythmias despite differences in cardiac electrophysiology. However, some mechanisms of arrhythmias in mice may differ from those in humans and therefore have to be extrapolated to the human situation with caution.

sur/kir6.X, katp channels. Annu. Rev. Physiol. 60, 667-687.

Babij, P., Askew, G. R., Nieuwenhuijsen, B., Su, C. M., Bridal, T. R., Jow, B., Argentieri, T. M., Kulik, J., DeGennaro, L. J., Spinelli, W., and Colatsky, T. J. (1998). Inhibition of cardiac delayed rectifier $\mathrm{k}^{+}$current by overexpression of the longqt syndrome herg g628s mutation in transgenic mice. Circ. Res. 83, 668-678.

Baker, L. C., Wolk, R., Choi, B R., Watkins, S., Plan, P., Shah, A., and Salama, G. (2004). Effects of mechanical uncouplers, diacetyl monoxime, and cytochalasin-d on the electrophysiology of perfused mouse hearts. Am. J. Physiol. Heart Circ. Physiol. 287, H1771-H1779.

Balasubramaniam, R., Grace, A. A. Saumarez, R. C., Vandenberg, J. I., and Huang, C. L. (2003). Electrogram prolongation and nifedipine-suppressible ventricular arrhythmias in mice following targeted disruption of kcnel. J. Physiol. (Lond.) 552, 535-546

Barnes, J. N., Casey, D. P., Hines, C. N., Nicholson, W. T., and Joyner, M. J. (2012). Cyclooxygenase inhibition augments central blood pressure and aortic wave reflection in aging humans. Am. J. Physiol. Heart Circ. Physiol. 302, H2629-H2634.

Baruscotti, M., Bucchi, A., Viscomi, C. Mandelli, G., Consalez, G., GnecchiRusconi, T., Montano, N., Casali, K. R., Micheloni, S., Barbuti, A. and DiFrancesco, D. (2011). Deep bradycardia and heart block caused by inducible cardiac-specific knockout of the pacemaker channel gene hcn4. Proc. Natl. Acad. Sci. U.S.A. 108, 1705-1710.

Barwe, S. P., Jordan, M. C., Skay, A. Inge, L., Rajasekaran, S. A., Wolle, D., Johnson, C. L., Neco, P., Fang, K., Rozengurt, N., Goldhaber, J. I., Roos, K. P., and Rajasekaran, A. K. (2009). Dysfunction of ouabaininduced cardiac contractility in mice with heart-specific ablation of na, k-atpase betal-subunit. J. Mol. Cell. Cardiol. 47, 552-560.

Bassani, J. W., Bassani, R. A., and Bers, D. M. (1994). Relaxation in rabbit and rat cardiac cells: speciesdependent differences in cellular mechanisms. J. Physiol. (Lond.) 476, 279-293.

Baudenbacher, F., Schober, T., Pinto, J. R., Sidorov, V. Y., Hilliard, F., Solaro, R. J., Potter, J. D., and Knollmann, B. C. (2008). Myofilament $\mathrm{ca}^{2+}$ sensitization causes susceptibility to cardiac arrhythmia in mice. J. Clin. Invest. 118, 3893-3903.

Beaumont, J., Davidenko, N. Davidenko, J. M., and Jalife, J. (1998). Spiral waves in twodimensional models of ventricular muscle: formation of a stationary core. Biophys. J. 75, 1-14.

Bers, D. M. (2002). Cardiac na/ca exchange function in rabbit, mouse and man: what's the difference? J. Mol. Cell. Cardiol. 34, 369-373. 
Bers, D. M., Bassani, R. A., Bassani, J. W., Baudet, S., and Hryshko, L. V. (1993). Paradoxical twitch potentiation after rest in cardiac muscle: increased fractional release of sr calcium. J. Mol. Cell. Cardiol. 25, 1047-1057.

Berul, C. I. (2003). Electrophysiological phenotyping in genetically engineered mice. Physiol. Genomics 13, 207-216.

Berul, C. I., Aronovitz, M. J., Wang, P. J., and Mendelsohn, M. E. (1996). In vivo cardiac electrophysiology studies in the mouse. Circulation 94, 2641-2648.

Betsuyaku, T., Kanno, S., Lerner, D. L., Schuessler, R. B., Saffitz, J. E., and Yamada, K. A. (2004). Spontaneous and inducible ventricular arrhythmias after myocardial infarction in mice. Cardiovasc. Pathol. 13, 156-164.

Bevilacqua, L. M., Simon, A. M., Maguire, C. T., Gehrmann, J., Wakimoto, H., Paul, D. L., and Berul, C. I. (2000). A targeted disruption in connexin40 leads to distinct atrioventricular conduction defects. J. Interv. Card. Electrophysiol. 4, 459-467.

Bienvenu, J. G., and Drolet, R. (1991). A quantitative study of cardiac ventricular mass in dogs. Can. J. Vet. Res. 55, 305-309.

Biermann, M., Rubart, M., Moreno, A., Wu, J., Josiah-Durant, A., and Zipes, D. P. (1998). Differential effects of cytochalasin $\mathrm{d}$ and 2, 3 butanedione monoxime on isometric twitch force and transmembrane action potential in isolated ventricular muscle: implications for optical measurements of cardiac repolarization. J. Cardiovasc. Electrophysiol. 9, 1348-1357.

Blaauw, Y., Gogelein, H., Tieleman, R. G., van Hunnik, A., Schotten, U., and Allessie, M. A. (2004). "Early" class iii drugs for the treatment of atrial fibrillation: efficacy and atrial selectivity of ave 0118 in remodeled atria of the goat. Circulation 110, 1717-1724.

Blair, E., Redwood, C., Ashrafian, H., Oliveira, M., Broxholme, J., Kerr, B., Salmon, A., Ostman-Smith, I., and Watkins, H. (2001). Mutations in the gamma(2) subunit of ampactivated protein kinase cause familial hypertrophic cardiomyopathy: evidence for the central role of energy compromise in disease pathogenesis. Hum. Mol. Genet. 10, 1215-1220.

Blana, A., Kaese, S., Fortmuller, L., Laakmann, S., Damke, D., Bragt, K. V., Eckstein, J., Piccini, I., Kirchhefer, U., Nattel, S., Breithardt,
G., Carmeliet, P., Carmeliet, E., Schotten, U., Verheule, S., Kirchhof, P., and Fabritz, L. (2010). Knock-in gain-of-function sodium channel mutation prolongs atrial action potentials and alters atrial vulnerability. Heart Rhythm 7, 1862-1869.

Boixel, C., Fontaine, V., Rucker-Martin, C., Milliez, P., Louedec, L., Michel, J. B., Jacob, M. P., and Hatem, S. N. (2003). Fibrosis of the left atria during progression of heart failure is associated with increased matrix metalloproteinases in the rat. J. Am. Coll. Cardiol. 42, 336-344.

Boulaksil, M., Winckels, S. K., Engelen, M. A., Stein, M., van Veen, T. A., Jansen, J. A., Linnenbank, A. C., Bierhuizen, M. F., Groenewegen, W. A., van Oosterhout, M. F., Kirkels, J. H., de Jonge, N., Varro, A., Vos, M. A., de Bakker, J. M., and van Rijen, H. V. (2010). Heterogeneous connexin 43 distribution in heart failure is associated with dispersed conduction and enhanced susceptibility to ventricular arrhythmias. Eur. J. Heart Fail. 12, 913-921.

Brands, M. W., Banes-Berceli, A. K., Inscho, E. W., Al-Azawi, H., Allen, A. J., and Labazi, H. (2010). Interleukin 6 knockout prevents angiotensin ii hypertension: role of renal vasoconstriction and janus kinase 2/signal transducer and activator of transcription 3 activation. Hypertension 56, 879-884.

Brouillette, J., Clark, R. B., Giles, W. R., and Fiset, C. (2004). Functional properties of $\mathrm{k}^{+}$currents in adult mouse ventricular myocytes. J. Physiol. (Lond.) 559, 777-798.

Bruneau, B. G., Nemer, G., Schmitt, J. P., Charron, F., Robitaille, L., Caron, S., Conner, D. A., Gessler, M., Nemer, M., Seidman, C. E., and Seidman, J. G. (2001). A murine model of holt-oram syndrome defines roles of the t-box transcription factor tbx 5 in cardiogenesis and disease. Cell 106, 709-721.

Carlstrom, M., Lai, E. Y., Ma, Z., Steege, A., Patzak, A., Eriksson, U. J., Lundberg, J. O., Wilcox, C. S., and Persson, A. E. (2010). Superoxide dismutase 1 limits renal microvascular remodeling and attenuates arteriole and blood pressure responses to angiotensin ii via modulation of nitric oxide bioavailability. Hypertension 56, 907-913.

Carroll, C. J., Suleman, N., Davidson, S. M., Faulkes, D. J., Diss, J. K., Knight, R., Stephanou, A., Latchman, D. S., and Townsend, P. A. (2011).
Transgenic overexpression of hsp56 does not result in cardiac hypertrophy nor protect from ischaemia/reperfusion injury. Int. J. Biochem. Cell Biol. 43, 74-79.

Cerrone, M., Colombi, B., Santoro, M., di Barletta, M. R., Scelsi, M., Villani, L., Napolitano, C., and Priori, S. G. (2005). Bidirectional ventricular tachycardia and fibrillation elicited in a knock-in mouse model carrier of a mutation in the cardiac ryanodine receptor. Circ. Res. 96 e77-e82.

Cerrone, M., Noujaim, S. F., Tolkacheva, E. G., Talkachou, A., O'Connell, R., Berenfeld, O., Anumonwo, J., Pandit, S. V., Vikstrom, K., Napolitano, C., Priori, S. G., and Jalife, J. (2007). Arrhythmogenic mechanisms in a mouse model of catecholaminergic polymorphic ventricular tachycardia. Circ. Res. 101, 1039-1048.

Chang, G. J., Su, M. J., Hung, L. M., and Lee, S. S. (2002). Cardiac electrophysiologic and antiarrhythmic actions of a pavine alkaloid derivative, o-methyl-neocaryachine, in rat heart. Br. J. Pharmacol. 136, 459-471.

Chen, J., Mandapati, R., Berenfeld, O., Skanes, A. C., Gray, R. A., and Jalife, J. (2000). Dynamics of wavelets and their role in atrial fibrillation in the isolated sheep heart. Cardiovasc. Res. 48, 220-232.

Cheung, D. W. (1981). Pulmonary vein as an ectopic focus in digitalisinduced arrhythmia. Nature 294 582-584.

Chiamvimonvat, V., Newman, D., Tang, A., Green, M., Mitchell, J., Wulffhart, Z., and Dorian, P. (1998). A double-blind placebo-controlled evaluation of the human electrophysiologic effects of zatebradine, a sinus node inhibitor. J. Cardiovasc Pharmacol. 32, 516-520.

Choi, E. K., Chang, P. C., Lee, Y. S., Lin, S. F., Zhu, W., Maruyama, M., Fishbein, M. C., Chen, Z., Rubartvon der Lohe, M., Field, L. J., and Chen, P. S. (2012). Triggered firing and atrial fibrillation in transgenic mice with selective atrial fibrosis induced by overexpression of tofbeta1. Circ. J. 76, 1354-1362.

Christoffels, V. M., Mommersteeg, M. T., Trowe, M. O., Prall, O. W., de Gier-de Vries, C., Soufan, A. T., Bussen, M., Schuster-Gossler, K., Harvey, R. P., Moorman, A. F., and Kispert, A. (2006). Formation of the venous pole of the heart from an nkx2-5-negative precursor population requires tbx18. Circ. Res. 98, 1555-1563.
Chua, S. K., Chang, P. C., Maruyama, M., Turker, I., Shinohara, T., Shen, M. J., Chen, Z., Shen, C., Rubartvon der Lohe, M., Lopshire, J. C., Ogawa, M., Weiss, J. N., Lin, S. F., Ai, T., and Chen, P. S. (2011). Smallconductance calcium-activated potassium channel and recurrent ventricular fibrillation in failing rabbit ventricles. Circ. Res. 108, 971-979.

Clemo, H. F., Stambler, B. S., and Baumgarten, C. M. (1998). Persistent activation of a swellingactivated cation current in ventricular myocytes from dogs with tachycardia-induced congestive heart failure. Circ. Res. 83, 147-157.

Cohen, M. I., Wieand, T. S., Rhodes, L. A., and Vetter, V. L. (1997). Electrophysiologic properties of the atrioventricular node in pediatric patients. J. Am. Coll. Cardiol. 29, 403-407.

Comtois, P., Kneller, J., and Nattel, S. (2005). Of circles and spirals: bridging the gap between the leading circle and spiral wave concepts of cardiac reentry. Europace 7(Suppl. 2), 10-20.

Cunha, D. F., Cunha, S. F., Reis, M. A., and Teixeira Vde, P. (2002). Heart weight and heart weight/body weight coefficient in malnourished adults. Arq. Bras. Cardiol. 78, 382-387.

Damkjaer, M., Vafaee, M., Braad, P. E., Petersen, H., Carlsen, P. F., and Bie, P. (2012). Renal cortical and medullary blood flow during modest saline loading in humans. Acta. Physiol. (Oxf.) 205, 472-483.

Danik, S., Cabo, C., Chiello, C., Kang, S., Wit, A. L., and Coromilas, J. (2002). Correlation of repolarization of ventricular monophasic action potential with ecg in the murine heart. Am. J. Physiol. Heart Circ. Physiol. 283, H372-H381.

Danik, S. B., Liu, F., Zhang, J., Suk, H. J., Morley, G. E., Fishman, G. I., and Gutstein, D. E. (2004). Modulation of cardiac gap junction expression and arrhythmic susceptibility. Circ. Res. 95, 1035-1041.

de Bakker, J. M., van Capelle, F. J., Janse, M. J., Tasseron, S., Vermeulen, J. T., de Jonge, N., and Lahpor, J. R. (1993). Slow conduction in the infarcted human heart. 'Zigzag' course of activation. Circulation 88, 915-926.

de Diego, C., Chen, F., Xie, L. H., Dave, A. S., Thu, M., Rongey, C., Weiss, J. N., and Valderrabano, M. (2008). Cardiac alternans in embryonic mouse ventricles. Am. 
J. Physiol. Heart Circ. Physiol. 294, H433-H440.

de Groot, J. R., Veenstra, T., Verkerk, A. O., Wilders, R., Smits, J. P., Wilms-Schopman, F. J., Wiegerinck, R. F., Bourier, J., Belterman, C. N., Coronel, R., and Verheijck, E. E. (2003). Conduction slowing by the gap junctional uncoupler carbenoxolone. Cardiovasc. Res. 60, 288-297.

de la Grandmaison, G. L., Clairand, I., and Durigon, M. (2001). Organ weight in 684 adult autopsies: new tables for a caucasoid population. Forensic Sci. Int. 119, 149-154.

Denes, P., Wu, D., Dhingra, R. C., Chuquimia, R., and Rosen, K. M. (1973). Demonstration of dual a-v nodal pathways in patients with paroxysmal supraventricular tachycardia. Circulation 48, 549-555.

Desai, K. H., Sato, R., Schauble, E., Barsh, G. S., Kobilka, B. K., and Bernstein, D. (1997). Cardiovascular indexes in the mouse at rest and with exercise: new tools to study models of cardiac disease. Am. J. Physiol. 272, H1053-H1061.

Despa, S., Islam, M. A., Pogwizd, S. M., and Bers, D. M. (2002). Intracellular $\left[\mathrm{na}^{+}\right]$and $\mathrm{na}^{+}$pump rate in rat and rabbit ventricular myocytes. J. Physiol. (Lond.) 539, 133-143.

de Waard, M. C., van der Velden, J., Bito, V., Ozdemir, S., Biesmans, L., Boontje, N. M., Dekkers, D. H., Schoonderwoerd, K., Schuurbiers, H. C., de Crom, R., Stienen, G. J., Sipido, K. R., Lamers, J. M., and Duncker, D. J. (2007). Early exercise training normalizes myofilament function and attenuates left ventricular pump dysfunction in mice with a large myocardial infarction. Circ. Res. 100, 1079-1088.

Dorian, P., Pinter, A., Mangat, I., Korley, V., Cvitkovic, S. S., and Beatch, G. N. (2007). The effect of vernakalant (rsd1235), an investigational antiarrhythmic agent, on atrial electrophysiology in humans. J. Cardiovasc. Pharmacol. 50, 35-40.

Douglas, Y. L., Jongbloed, M. R., Deruiter, M. C., and Gittenbergerde Groot, A. C. (2011). Normal and abnormal development of pulmonary veins: state of the art and correlation with clinical entities. Int. J. Cardiol. 147, 13-24.

Drici, M. D., Arrighi, I., Chouabe, C., Mann, J. R., Lazdunski, M., Romey, G., and Barhanin, J. (1998). Involvement of isk-associated $\mathrm{k}^{+}$ channel in heart rate control of repolarization in a murine engineered model of jervell and langenielsen syndrome. Circ. Res. 83, 95-102.
Durrer, D., van Dam, R. T., Freud, G. E., Janse, M. J., Meijler, F. L., and Arzbaecher, R. C. (1970). Total excitation of the isolated human heart. Circulation 41, 899-912.

Edvardsson, N., Hirsch, I., and Olsson, S. B. (1984). Right ventricular monophasic action potentials in healthy young men. Pacing Clin. Electrophysiol. 7, 813-821.

Etzion, Y., Mor, M., Shalev, A., Dror, S., Etzion, O., Dagan, A., Beharier, O., Moran, A., and Katz, A. (2008). New insights into the atrial electrophysiology of rodents using a novel modality: the miniature-bipolar hook electrode. Am. J. Physiol. Heart Circ. Physiol. 295, H1460-H1469.

Fabritz, L., Damke, D., Emmerich, M., Kaufmann, S. G., Theis, K., Blana, A., Fortmuller, L., Laakmann, S., Hermann, S., Aleynichenko, E., Steinfurt, J., Volkery, D., Riemann, B., Kirchhefer, U., Franz, M. R., Breithardt, G., Carmeliet, E., Schafers, M., Maier, S. K., Carmeliet, P., and Kirchhof, P. (2010). Autonomic modulation and antiarrhythmic therapy in a model of long qt syndrome type 3 . Cardiovasc. Res. 87, 60-72.

Fabritz, L., Kirchhof, P., Fortmuller, L., Auchampach, J. A., Baba, H. A., Breithardt, G., Neumann, J., Boknik, P., and Schmitz, W. (2004). Gene dose-dependent atrial arrhythmias, heart block, and brady-cardiomyopathy in mice overexpressing $\mathrm{a}(3)$ adenosine receptors. Cardiovasc. Res. 62, 500-508.

Fabritz, L., Kirchhof, P., Franz, M. R., Eckardt, L., Monnig, G., Milberg, P., Breithardt, G., and Haverkamp, W. (2003). Prolonged action potential durations, increased dispersion of repolarization, and polymorphic ventricular tachycardia in a mouse model of proarrhythmia. Basic Res. Cardiol. 98, 25-32.

Fareh, S., Villemaire, C., and Nattel, S. (1998). Importance of refractoriness heterogeneity in the enhanced vulnerability to atrial fibrillation induction caused by tachycardiainduced atrial electrical remodeling. Circulation 98, 2202-2209.

Fedorov, V. V., Lozinsky, I. T., Sosunov, E. A., Anyukhovsky, E. P., Rosen, M. R., Balke, C. W., and Efimov, I. R. (2007). Application of blebbistatin as an excitation-contraction uncoupler for electrophysiologic study of rat and rabbit hearts. Heart Rhythm 4, 619-626.

Fenske, S., Mader, R., Scharr, A., Paparizos, C., Cao-Ehlker, X., Michalakis, S., Shaltiel, L., Weidinger, M., Stieber, J., Feil, S.,
Feil, R., Hofmann, F., Wahl-Schott, C., and Biel, M. (2011). Hcn3 contributes to the ventricular action potential waveform in the murine heart. Circ. Res. 109, 1015-1023.

Flagg, T. P., and Nichols, C. G. (2001) Sarcolemmal k(atp) channels in the heart: molecular mechanisms brought to light, but physiologic consequences still in the dark. J. Cardiovasc. Electrophysiol. 12, 1195-1198.

Frank, D. U., Carter, K. L., Thomas, K. R., Burr, R. M., Bakker, M. L., Coetzee, W. A., Tristani-Firouzi, M. Bamshad, M. J., Christoffels, V. M., and Moon, A. M. (2012). Lethal arrhythmias in tbx3-deficient mice reveal extreme dosage sensitivity of cardiac conduction system function and homeostasis. Proc. Natl. Acad. Sci. U.S.A. 109, E154-E163.

Franz, M. R., Bargheer, K., Rafflenbeul, W., Haverich, A., and Lichtlen, P. R. (1987). Monophasic action potential mapping in human subjects with normal electrocardiograms: direct evidence for the genesis of the $\mathrm{t}$ wave. Circulation 75 , 379-386.

Garrey, W. E. (1924). Auricular fibrillation. Physiol. Rev. 4, 215-250.

Gehrmann, J., and Berul, C. I. (2000). Cardiac electrophysiology in genetically engineered mice. J. Cardiovasc. Electrophysiol. 11, 354-368.

Gehrmann, J., Frantz, S., Maguire, C. T., Vargas, M., Ducharme, A., Wakimoto, H., Lee, R. T., and Berul, C. I. (2001). Electrophysiological characterization of murine myocardial ischemia and infarction. Basic Res. Cardiol. 96, 237-250.

Gehrmann, J., Hammer, P. E., Maguire, C. T., Wakimoto, H., Triedman, J. K., and Berul, C. I. (2000). Phenotypic screening for heart rate variability in the mouse. Am. J. Physiol. Heart Circ. Physiol. 279, H733-H740.

Georgakopoulos, D., and Kass, D. (2001). Minimal force-frequency modulation of inotropy and relaxation of in situ murine heart J. Physiol. (Lond.) 534, 535-545.

Gittenberger-de Groot, A. C., Mahtab, E. A., Hahurij, N. D., Wisse, L. J., Deruiter, M. C., Wijffels, M. C., and Poelmann, R. E. (2007). Nkx2.5-negative myocardium of the posterior heart field and its correlation with podoplanin expression in cells from the developing cardiac pacemaking and conduction system. Anat. Rec. (Hoboken) 290, 115-122.

Glukhov, A. V., Fedorov, V. V., Anderson, M. E., Mohler, P. J., and Efimov, I. R. (2010). Functional anatomy of the murine sinus node: high-resolution optical mapping of ankyrin-b heterozygous mice. Am J. Physiol. Heart Circ. Physiol. 299, $\mathrm{H} 482-\mathrm{H} 491$.

Goldhaber, J. I., Henderson, S. A., Reuter, H., Pott, C., and Philipson, K. D. (2005). Effects of $\mathrm{na}^{+}-\mathrm{ca}^{2+}$ exchange expression on excitationcontraction coupling in genetically modified mice. Ann. N.Y. Acad. Sci. 1047, 122-126.

Gollob, M. H., Green, M. S., Tang, A. S., Gollob, T., Karibe, A., Ali Hassan, A. S., Ahmad, F., Lozado, R. Shah, G., Fananapazir, L., Bachinski, L. L., and Roberts, R. (2001) Identification of a gene responsible for familial wolff-parkinson-white syndrome. N. Engl. J. Med. 344, 1823-1831.

Golshayan, D., Seydoux, C., Berguer, D. G., Stumpe, F., Hurni, M. Ruchat, P., Fischer, A., Mueller, X. Sadeghi, H., von Segesser, L., and Goy, J. J. (1998). Incidence and prognostic value of electrocardiographic abnormalities after heart transplantation. Clin. Cardiol. 21, 680-684.

Gourdie, R. G., Harris, B. S., Bond, J. Justus, C., Hewett, K. W., O’Brien, T. X., Thompson, R. P., and Sedmera, D. (2003). Development of the cardiac pacemaking and conduction system. Birth Defects Res. C. Embryo Today 69, 46-57.

Grandy, S. A., Trepanier-Boulay, V., and Fiset, C. (2007). Postnatal development has a marked effect on ventricular repolarization in mice. $A m$. J. Physiol. Heart Circ. Physiol. 293, H2168-H2177.

Grecu, M., Floria, M., and Georgescu, C. A. (2009). Abnormal atrioventricular node conduction and atrioventricular nodal reentrant tachycardia in patients older versus younger than 65 years of age. Pacing Clin. Electrophysiol. 32(Suppl. 1), S98-S100.

Greener, I. D., Monfredi, O., Inada, S., Chandler, N. J., Tellez, J. O., Atkinson, A., Taube, M. A., Billeter R., Anderson, R. H., Efimov, I. R., Molenaar, P., Sigg, D. C., Sharma, V., Boyett, M. R., and Dobrzynski, H. (2011). Molecular architecture of the human specialised atrioventricular conduction axis. J. Mol. Cell. Cardiol. 50, 642-651.

Gros, D., Theveniau-Ruissy, M., Bernard, M., Calmels, T., Kober, F., Sohl, G., Willecke, K., Nargeot, J., Jongsma, H. J., and Mangoni, M. E. (2010). Connexin 30 is expressed in the mouse sino-atrial node and modulates heart rate. Cardiovasc. Res. 85, 45-55. 
Guo, W., Xu, H., London, B., and Nerbonne, J. M. (1999). Molecular basis of transient outward $\mathrm{k}^{+}$current diversity in mouse ventricular myocytes. J. Physiol. (Lond.) 521(Pt 3), 587-599.

Gutstein, D. E., Danik, S. B., Sereysky, J. B., Morley, G. E., and Fishman, G. I. (2003). Subdiaphragmatic murine electrophysiological studies: sequential determination of ventricular refractoriness and arrhythmia induction. Am. J. Physiol. Heart Circ. Physiol. 285, H1091-H1096.

Gutstein, D. E., Morley, G. E., Tamaddon, H., Vaidya, D., Schneider, M. D., Chen, J., Chien, K. R., Stuhlmann, H., and Fishman, G. I. (2001). Conduction slowing and sudden arrhythmic death in mice with cardiac-restricted inactivation of connexin43. Circ. Res. 88, 333-339.

Hagendorff, A., Schumacher, B., Kirchhoff, S., Luderitz, B., and Willecke, K. (1999). Conduction disturbances and increased atrial vulnerability in connexin40deficient mice analyzed by transesophageal stimulation. Circulation 99, 1508-1515.

Haissaguerre, M., Jais, P., Shah, D. C., Takahashi, A., Hocini, M., Quiniou, G., Garrigue, S., Le Mouroux, A., Le Metayer, P., and Clementy, J. (1998). Spontaneous initiation of atrial fibrillation by ectopic beats originating in the pulmonary veins. N. Engl. J. Med. 339, 659-666.

Hansson, A., Holm, M., Blomstrom, P., Johansson, R., Luhrs, C., Brandt, J., and Olsson, S. B. (1998). Right atrial free wall conduction velocity and degree of anisotropy in patients with stable sinus rhythm studied during open heart surgery. Eur. Heart J. 19, 293-300.

Hao, X., Zhang, Y., Zhang, X., Nirmalan, M., Davies, L., Konstantinou, D., Yin, F., Dobrzynski, H., Wang, X., Grace, A., Zhang, H., Boyett, M., Huang, C. L., and Lei, M. (2011). Tgfbetal-mediated fibrosis and ion channel remodeling are key mechanisms in producing the sinus node dysfunction associated with scn5a deficiency and aging. Circ. Arrhythm Electrophysiol. 4, 397-406.

Harris, B. S., Baicu, C. F., Haghshenas, N., Kasiganesan, H., Scholz, D., Rackley, M. S., Miquerol, L., Gros, D., Mukherjee, R., and O'Brien, T. X. (2012). Remodeling of the peripheral cardiac conduction system in response to pressure overload. Am. J. Physiol. Heart Circ. Physiol. 302, H1712-H1725.
Haugan, K., Kjolbye, A. L., Hennan, J. K., and Petersen, J. S. (2005). Rotigaptide (zp123) reverts established atrial conduction velocity slowing. Cell Commun. Adhes. 12, 271-278.

He, G., Hu, J., Li, T., Ma, X., Meng, J., Jia, M., Lu, J., Ohtsu, H., Chen, Z., and Luo, X. (2012) Arrhythmogenic effect of sympathetic histamine in mouse hearts subjected to acute ischemia. Mol. Med. 18, 1-9.

Henderson, S. A., Goldhaber, J. I., So, J. M., Han, T., Motter, C. Ngo, A., Chantawansri, C., Ritter, M. R., Friedlander, M., Nicoll, D. A., Frank, J. S., Jordan, M. C., Roos, K. P., Ross, R. S., and Philipson, K. D. (2004). Functional adult myocardium in the absence of $\mathrm{na}^{+}-\mathrm{ca}^{2+}$ exchange: cardiac-specific knockout of ncxl. Circ. Res. 95, 604-611.

Herrmann, S., Hofmann, F., Stieber, J., and Ludwig, A. (2012). Hcn channels in the heart: lessons from mouse mutants. Br. J. Pharmacol. 166, 501-509.

Herrmann, S., Layh, B., and Ludwig, A. (2011). Novel insights into the distribution of cardiac hon channels: an expression study in the mouse heart. J. Mol. Cell. Cardiol. 51, 997-1006.

Herrmann, S., Stieber, J., Stockl, G. Hofmann, F., and Ludwig, A. (2007). Hcn 4 provides a 'depolarization reserve' and is not required for heart rate acceleration in mice. Embo. J. 26, 4423-4432.

Hill, J. A., Karimi, M., Kutschke, W., Davisson, R. L., Zimmerman, K., Wang, Z., Kerber, R. E., and Weiss, R. M. (2000). Cardiac hypertrophy is not a required compensatory response to short-term pressure overload. Circulation 101, 2863-2869.

Hirose, M., Takeishi, Y., Miyamoto, T., Kubota, I., Laurita, K. R., and Chiba, S. (2005). Mechanism for atrial tachyarrhythmia in chronic volume overload-induced dilated atria. J. Cardiovasc. Electrophysiol. 16, 760-769.

Hoesl, E., Stieber, J., Herrmann, S., Feil, S., Tybl, E., Hofmann, F., Feil, R., and Ludwig, A. (2008). Tamoxifeninducible gene deletion in the cardiac conduction system. J. Mol. Cell. Cardiol. 45, 62-69.

Hong, C. S., Kwon, S. J., Cho, M. C., Kwak, Y. G., Ha, K. C., Hong, B., Li, H., Chae, S. W., Chai, O. H., Song, C. H., Li, Y., Kim, J. C., Woo, S. H., Lee, S. Y., Lee, C. O., and Kim do, H. (2008). Overexpression of junctate induces cardiac hypertrophy and arrhythmia via altered calcium handling. J. Mol. Cell. Cardiol. 44, 672-682.

Hoogaars, W. M., Engel, A., Brons, J. F. Verkerk, A. O., de Lange, F. J., Wong, L. Y., Bakker, M. L., Clout, D. E., Wakker, V., Barnett, P., Ravesloot, J. H., Moorman, A. F., Verheijck, E. E., and Christoffels, V. M. (2007). Tbx3 controls the sinoatrial node gene program and imposes pacemaker function on the atria. Genes Dev. 21, 1098-1112.

Hyyti, O. M., Ledee, D., Ning, X. H., Ge, M., and Portman, M. A. (2010). Aging impairs myocardial fatty acid and ketone oxidation and modifies cardiac functional and metabolic responses to insulin in mice. Am. J. Physiol. Heart Circ. Physiol. 299, H868-H875.

Imahashi, K., Pott, C., Goldhaber J. I., Steenbergen, C., Philipson, K. D., and Murphy, E. (2005). Cardiac-specific ablation of the $\mathrm{na}^{+}-\mathrm{Ca}^{2+}$ exchanger confers protection against ischemia/reperfusion injury. Circ. Res. 97, 916-921.

Inagaki, K., Begley, R., Ikeno, F., and Mochly-Rosen, D. (2005) Cardioprotection by epsilonprotein kinase $\mathrm{c}$ activation from ischemia: continuous delivery and antiarrhythmic effect of an epsilonprotein kinase c-activating peptide. Circulation 111, 44-50.

Jalife, J., Berenfeld, O., and Mansour, M. (2002). Mother rotors and fibrillatory conduction: a mechanism of atrial fibrillation. Cardiovasc. Res. 54, 204-216.

Jalife, J., Morley, G. E., and Vaidya, D. (1999). Connexins and impulse propagation in the mouse heart. J. Cardiovasc. Electrophysiol. 10, 1649-1663.

Jansen, J. A., van Veen, T. A., de Jong, S. van der Nagel, R., van Stuijvenberg, L., Driessen, H., Labzowski, R., Oefner, C. M., Bosch, A. A., Nguyen, T. Q., Goldschmeding, R., Vos, M. A., de Bakker, J. M., and van Rijen, H. V. (2012). Reduced cx43 expression triggers increased fibrosis due to enhanced fibroblast activity. Circ. Arrhythm Electrophysiol. 5, 380-390.

Janssen, B. J., Leenders, P. J., and Smits, J. F. (2000). Short-term and longterm blood pressure and heart rate variability in the mouse. Am. J. Physiol. Regul. Integr. Comp. Physiol. 278, R215-R225.

Janssen, B. J., and Smits, J. F. (2002) Autonomic control of blood pressure in mice: basic physiology and effects of genetic modification. Am. J. Physiol. Regul. Integr. Comp. Physiol. 282, R1545-R1564.
Jay, P. Y., Harris, B. S., Maguire, C. T., Buerger, A., Wakimoto, H., Tanaka, M., Kupershmidt, S., Roden, D. M. Schultheiss, T. M., O’Brien, T. X., Gourdie, R. G., Berul, C. I., and Izumo, S. (2004). Nkx2-5 mutation causes anatomic hypoplasia of the cardiac conduction system. J. Clin. Invest. 113, 1130-1137.

Johnstone, A. M., Murison, S. D., Duncan, J. S., Rance, K. A., and Speakman, J. R. (2005). Factors influencing variation in basal metabolic rate include fat-free mass, fat mass, age, and circulating thyroxine but not sex, circulating leptin, or triiodothyronine. Am. J. Clin. Nutr. 82, 941-948.

Jongbloed, M. R., Schalij, M. J., Poelmann, R. E., Blom, N. A., Fekkes, M. L., Wang, Z., Fishman, G. I., and Gittenberger-De Groot, A. C. (2004). Embryonic conduction tissue: a spatial correlation with adult arrhythmogenic areas. J. Cardiovasc. Electrophysiol. 15, 349-355.

Joyner, R. W., Wang, Y. G., Wilders, R., Golod, D. A., Wagner, M. B., Kumar, R., and Goolsby, W. N. (2000). A spontaneously active focus drives a model atrial sheet more easily than a model ventricular sheet. Am. J. Physiol. Heart Circ. Physiol. 279, H752-H763.

Joyner, R. W., Wilders, R., and Wagner, M. B. (2007). Propagation of pacemaker activity. Med. Biol. Eng. Comput. 45, 177-187.

Just, A., Faulhaber, J., and Ehmke, H. (2000). Autonomic cardiovascular control in conscious mice. Am. Physiol. Regul. Integr. Comp. Physiol. 279, R2214-R2221.

Kasahara, H., Wakimoto, H., Liu, M., Maguire, C. T., Converso, K. L., Shioi, T., Huang, W. Y., Manning, W. J., Paul, D., Lawitts, J., Berul, C. I., and Izumo, S. (2001). Progressive atrioventricular conduction defects and heart failure in mice expressing a mutant csx/nkx2.5 homeoprotein. J. Clin. Invest. 108, 189-201.

Kasper, D. L., Braunwald, E., Fauci, A. S., Hauser, S. L., Longo, D. L., Jameson, J. L., and Loscalzo, J., (2008). Harrison's Principles of Internal Medicine, 17th Edn. New York, NY: Mcgraw-Hill Medical Publishing Division.

Kass, D. A., Hare, J. M., and Georgakopoulos, D. (1998). Murine cardiac function: a cautionary tail. Circ. Res. 82, 519-522.

Killeen, M. J., Gurung, I. S., Thomas, G., Stokoe, K. S., Grace, A. A., and Huang, C. L. (2007a). Separation of early afterdepolarizations from arrhythmogenic substrate in the 
isolated perfused hypokalaemic murine heart through modifiers of calcium homeostasis. Acta Physiol. (Oxf.) 191, 43-58.

Killeen, M. J., Thomas, G., Gurung, I. S., Goddard, C. A., Fraser, J. A., Mahaut-Smith, M. P., Colledge, W. H., Grace, A. A., and Huang, C. L. (2007b). Arrhythmogenic mechanisms in the isolated perfused hypokalaemic murine heart. Acta Physiol. (Oxf.) 189, 33-46.

Kirchhof, P., Marijon, E., Fabritz, L., Li, N., Wang, W., Wang, T., Schulte, K., Hanstein, J., Schulte, J. S., Vogel, M., Mougenot, N., Laakmann, S., Fortmueller, L., Eckstein, J., Verheule, S., Kaese, S., Staab, A., Grote-Wessels, S., Schotten, U., Moubarak, G., Wehrens, X. H., Schmitz, W. Hatem, S., and Muller, F. U. (2011). Overexpression of camp-response element modulator causes abnormal growth and development of the atrial myocardium resulting in a substrate for sustained atrial fibrillation in mice. Int. J. Cardiol. doi: 10.1016/j.ijcard.2011.10.057. [Epub ahead of print].

Knollmann, B. C., Katchman, A. N., and Franz, M. R. (2001). Monophasic action potential recordings from intact mouse heart: validation, regional heterogeneity, and relation to refractoriness. J. Cardiovasc. Electrophysiol. 12, 1286-1294.

Knollmann, B. C., Schober, T., Petersen, A. O., Sirenko, S. G., and Franz, M. R. (2007). Action potential characterization in intact mouse heart: steady-state cycle length dependence and electrical restitution. Am. J. Physiol. Heart Circ. Physiol. 292, H614-H621.

Korte, T., Fuchs, M., Guener, Z., Bonin, J., de Sousa, M., Niehaus, M., Tebbenjohanns, J., and Drexler, H. (2002). In-vivo electrophysiological study in mice with chronic anterior myocardial infarction. J. Interv. Card. Electrophysiol. 6, 121-132.

Kose, S., Amasyali, B., Aytemir, K., Kilic, A., Can, I., Kursaklioglu, H., Celik, T., and Isik, E. (2004). Atrioventricular nodal reentrant tachycardia with multiple discontinuities in the atrioventricular node conduction curve: immediate success rates of radiofrequency ablation and long-term clinical follow-up results as compared to patients with single or no ah-jumps. J. Interv. Card. Electrophysiol. 10, 249-254.

Koura, T., Hara, M., Takeuchi, S., Ota, K., Okada, Y., Miyoshi,
S., Watanabe, A., Shiraiwa, K., Mitamura, H., Kodama, I., and Ogawa, S. (2002). Anisotropic conduction properties in canine atria analyzed by high-resolution optical mapping: preferential direction of conduction block changes from longitudinal to transverse with increasing age. Circulation 105, 2092-2098.

Kovoor, P., Wickman, K., Maguire, C. T., Pu, W., Gehrmann, J., Berul, C. I., and Clapham, D. E. (2001). Evaluation of the role of $\mathrm{i}(\mathrm{kach})$ in atrial fibrillation using a mouse knockout model. J. Am. Coll. Cardiol. 37, 2136-2143.

Koyama, M., Heerdt, P. M., and Levi, R. (2003). Increased severity of reperfusion arrhythmias in mouse hearts lacking histamine h3-receptors. Biochem. Biophys. Res. Commun. 306, 792-796.

Kreuzberg, M. M., Schrickel, J. W. Ghanem, A., Kim, J. S., Degen, J., Janssen-Bienhold, U., Lewalter, T., Tiemann, K., and Willecke, K. (2006). Connexin 30.2 containing gap junction channels decelerate impulse propagation through the atrioventricular node. Proc. Natl. Acad. Sci. U.S.A. 103, 5959-5964.

Kruger, O., Maxeiner, S., Kim, J. S. van Rijen, H. V., de Bakker, J. M., Eckardt, D., Tiemann, K., Lewalter T., Ghanem, A., Luderitz, B., and Willecke, K. (2006). Cardiac morphogenetic defects and conduction abnormalities in mice homozygously deficient for connexin 40 and heterozygously deficient for connexin45. J. Mol. Cell. Cardiol. 41, 787-797.

Lang, D., Sulkin, M., Lou, Q., and Efimov, I. R. (2011). Optical mapping of action potentials and calcium transients in the mouse heart. J. Vis. Exp. 55, e3275.

Later, W., Bosy-Westphal, A., Kossel, E., Gluer, C. C., Heller, M., and Muller, M. J. (2010). Is the 1975 reference man still a suitable reference? Eur. J. Clin. Nutr. 64, 1035-1042.

Leaf, D. E., Feig, J. E., Vasquez, C., Riva, P. L., Yu, C., Lader, J. M., Kontogeorgis, A., Baron, E. L., Peters, N. S., Fisher, E. A., Gutstein, D. E., and Morley, G. E. (2008). Connexin40 imparts conduction heterogeneity to atrial tissue. Circ. Res. 103, 1001-1008.

Lei, M., Goddard, C., Liu, J., Leoni, A. L., Royer, A., Fung, S. S., Xiao, G., Ma, A., Zhang, H., Charpentier, F., Vandenberg, J. I., Colledge, W. H., Grace, A. A., and Huang, C. L. (2005). Sinus node dysfunction following targeted disruption of the murine cardiac sodium channel gene scn5a. J. Physiol. (Lond.) 567, 387-400.

Li, G. R., Feng, J., Yue, L., Carrier, M. and Nattel, S. (1996). Evidence for two components of delayed rectifier $\mathrm{k}^{+}$current in human ventricular myocytes. Circ. Res. 78, 689-696.

Li, J., McLerie, M., and Lopatin, A. N. (2004). Transgenic upregulation of ikl in the mouse heart leads to multiple abnormalities of cardiac excitability. Am. J. Physiol. Hear Circ. Physiol. 287, H2790-H2802.

Li, N., Timofeyev, V., Tuteja, D., Xu, D., Lu, L., Zhang, Q., Zhang, Z., Singapuri, A., Albert, T. R., Rajagopal, A. V., Bond, C. T. Periasamy, M., Adelman, J. and Chiamvimonvat, N. (2009) Ablation of a $\mathrm{ca}^{2+}$-activated $\mathrm{k}^{+}$ channel (sk2 channel) results in action potential prolongation in atrial myocytes and atrial fibrillation. J. Physiol. (Lond.) 587, 1087-1100.

Li, N., Wang, T., Wang, W., Cutler, M. J., Wang, Q., Voigt, N., Rosenbaum, D. S., Dobrev, D., and Wehrens, X. H. (2012). Inhibition of camkii phosphorylation of ryr2 prevents induction of atrial fibrillation in fkbp12.6 knockout mice. Circ. Res. $110,465-470$.

Liao, C. H., Akazawa, H., Tamagawa M., Ito, K., Yasuda, N., Kudo, Y., Yamamoto, R., Ozasa, Y., Fujimoto, M., Wang, P., Nakauchi, H., Nakaya, H., and Komuro, I. (2010). Cardiac mast cells cause atrial fibrillation through pdgf-a-mediated fibrosis in pressure-overloaded mouse hearts. J. Clin. Invest. 120 242-253.

Lindner, M., Erdmann, E., and Beuckelmann, D. J. (1998). Calcium content of the sarcoplasmic reticulum in isolated ventricular myocytes from patients with terminal heart failure. J. Mol. Cell. Cardiol. 30, 743-749.

Liu, G., Iden, J. B., Kovithavongs, K. Gulamhusein, R., Duff, H. J., and Kavanagh, K. M. (2004). In vivo temporal and spatial distribution of depolarization and repolarization and the illusive murine $\mathrm{t}$ wave. J. Physiol. (Lond.) 555, 267-279.

Liu, J., Dobrzynski, H., Yanni, J., Boyett, M. R., and Lei, M. (2007) Organisation of the mouse sinoatrial node: structure and expression of hon channels. Cardiovasc. Res. 73 , 729-738.

London, B., Baker, L. C., PetkovaKirova, P., Nerbonne, J. M., Choi, B. R., and Salama, G. (2007). Dispersion of repolarization and refractoriness are determinants of arrhythmia phenotype in transgenic mice with long qt. J. Physiol. (Lond.) $578,115-129$.

Lopatin, A. N., and Nichols, C. G. (2001). Inward rectifiers in the heart: an update on i(k1). J. Mol. Cell. Cardiol. 33, 625-638.

Ludwig, A., Budde, T., Stieber, J., Moosmang, S., Wahl, C., Holthoff, K., Langebartels, A., Wotjak, C., Munsch, T., Zong, X., Feil, S., Feil, R., Lancel, M., Chien, K. R., Konnerth, A., Pape, H. C., Biel, M., and Hofmann, F. (2003). Absence epilepsy and sinus dysrhythmia in mice lacking the pacemaker channel hon2. Embo. J. 22, 216-224.

Ludwig, A., Herrmann, S., Hoesl, E., and Stieber, J. (2008). Mouse models for studying pacemaker channel function and sinus node arrhythmia. Prog. Biophys. Mol. Biol. 98, 179-185.

Maass, K., Chase, S. E., Lin, X., and Delmar, M. (2009). Cx43 ct domain influences infarct size and susceptibility to ventricular tachyarrhythmias in acute myocardial infarction. Cardiovasc. Res. 84, 361-367.

Maguire, C. T., Bevilacqua, L. M. Wakimoto, H., Gehrmann, J., and Berul, C. I. (2000). Maturational atrioventricular nodal physiology in the mouse. J. Cardiovasc. Electrophysiol. 11, 557-564.

Mancarella, S., Yue, Y., Karnabi, E., Qu, Y., El-Sherif, N., and Boutjdir, M. (2008). Impaired $\mathrm{ca}^{2+}$ homeostasis is associated with atrial fibrillation in the alphald l-type $\mathrm{ca}^{2+}$ channel ko mouse. Am. J. Physiol. Heart Circ. Physiol. 295, H2017-H2024.

Mancia, G., Ferrari, A., Gregorini, L., Parati, G., Pomidossi, G., Bertinieri, G., Grassi, G., di Rienzo, M., Pedotti, A., and Zanchetti, A (1983). Blood pressure and heart rate variabilities in normotensive and hypertensive human beings. Circ. Res. 53, 96-104.

Mangoni, M. E., Couette, B., Bourinet, E., Platzer, J., Reimer, D., Striessnig, J., and Nargeot, J. (2003). Functional role of 1-type cav1.3 $\mathrm{Ca}^{2+}$ channels in cardiac pacemaker activity. Proc. Natl. Acad. Sci. U.S.A. 100, 5543-5548.

Mansier, P., Medigue, C., Charlotte, N., Vermeiren, C., Coraboeuf, E., Deroubai, E., Ratner, E., Chevalier, B., Clairambault, J., Carre, F., Dahkli, T., Bertin, B., Briand, P., Strosberg, D., and Swynghedauw, B. (1996). Decreased heart rate variability in transgenic mice overexpressing atrial beta 1adrenoceptors. Am. J. Physiol. 271, H1465-H1472.

Martin, C. A., Zhang, Y., Grace, A. A., and Huang, C. L. (2010). Increased 
right ventricular repolarization gradients promote arrhythmogenesis in a murine model of brugada syndrome. J. Cardiovasc. Electrophysiol. 21, 1153-1159.

Maslov, M. Y., Chacko, V. P., Hirsch, G. A., Akki, A., Leppo, M. K., Steenbergen, C., and Weiss, R. G. (2010). Reduced in vivo high-energy phosphates precede adriamycininduced cardiac dysfunction. Am. J. Physiol. Heart Circ. Physiol. 299, H332-H337.

Mathur, N., Sood, S., Wang, S., van Oort, R. J., Sarma, S., Li, N., Skapura, D. G., Bayle, J. H., Valderrabano, M., and Wehrens, X. H. (2009). Sudden infant death syndrome in mice with an inherited mutation in ryr2. Circ. Arrhythm Electrophysiol. 2, 677-685.

Meijler, F. L., Billette, J., Jalife, J., Kik, M. J., Reiber, J. H., Stokhof, A. A., Westenberg, J. J., Wassenaar, C., and Strackee, J. (2005). Atrioventricular conduction in mammalian species: hemodynamic and electrical scaling. Heart Rhythm 2, 188-196.

Menzies-Gow, N. J., Bailey, S. R., Stevens, K., Katz, L., Elliott, J., and Marr, C. M. (2005). Digital blood flow and plasma endothelin concentration in clinically endotoxemic horses. Am. J. Vet. Res. 66, 630-636.

Mestas, J., and Hughes, C. C. (2004). Of mice and not men: differences between mouse and human immunology. J. Immunol. 172, 2731-2738.

Michael, L. H., Entman, M. L., Hartley, C. J., Youker, K. A., Zhu, J., Hall, S. R., Hawkins, H. K., Berens, K., and Ballantyne, C. M. (1995). Myocardial ischemia and reperfusion: a murine model. Am. J. Physiol. 269, H2147-H2154.

Milanesi, R., Baruscotti, M., GnecchiRuscone, T., and DiFrancesco, D. (2006). Familial sinus bradycardia associated with a mutation in the cardiac pacemaker channel. N. Engl. J. Med. 354, 151-157.

Mitchell, G. F., Jeron, A., and Koren, G. (1998). Measurement of heart rate and q-t interval in the conscious mouse. Am. J. Physiol. 274, H747-H751.

Mommersteeg, M. T., Hoogaars, W. M., Prall, O. W., de Gier-de Vries, C., Wiese, C., Clout, D. E., Papaioannou, V. E., Brown, N. A., Harvey, R. P., Moorman, A. F., and Christoffels, V. M. (2007). Molecular pathway for the localized formation of the sinoatrial node. Circ. Res. 100, 354-362.

Monnig, G., Wessling, J., Juergens, K. U., Milberg, P., Ribbing, M., Fischbach, R., Wiekowski, J.,
Breithardt, G., and Eckardt, L. (2005). Further evidence of a close anatomical relation between the oesophagus and pulmonary veins. Europace 7, 540-545.

Monnig, G., Wessling, J., Juergens, K. U., Milberg, P., Ribbing, M., Fischbach, R., Wiekowski, J., Breithardt, G., and Eckardt, L. (2005). Further evidence of a close anatomical relation between the oesophagus and pulmonary veins. Europace 7, 540-545.

Morley, G. E., Vaidya, D., Samie, F. H., Lo, C., Delmar, M., and Jalife, J. (1999). Characterization of conduction in the ventricles of normal and heterozygous cx43 knockout mice using optical mapping. J. Cardiovasc. Electrophysiol. 10, 1361-1375.

Moskowitz, I. P., Kim, J. B., Moore, M. L., Wolf, C. M., Peterson, M. A., Shendure, J., Nobrega, M. A., Yokota, Y., Berul, C., Izumo, S., Seidman, J. G., and Seidman, C. E. (2007). A molecular pathway including id2, tbx5, and nkx25 required for cardiac conduction system development. Cell 129, 1365-1376.

Muller, F. U., Lewin, G., Baba, H. A., Boknik, P., Fabritz, L., Kirchhefer, U., Kirchhof, P., Loser, K., Matus, M., Neumann, J., Riemann, B. and Schmitz, W. (2005). Heartdirected expression of a human cardiac isoform of camp-response element modulator in transgenic mice. J. Biol. Chem. 280, 6906-6914.

Nagy, N., Szuts, V., Horvath, Z., Seprenyi, G., Farkas, A. S., Acsai K., Prorok, J., Bitay, M., Kun, A., Pataricza, J., Papp, J. G., Nanasi, P. P., Varro, A., and Toth, A. (2009). Does small-conductance calciumactivated potassium channel contribute to cardiac repolarization? J. Mol. Cell. Cardiol. 47, 656-663.

Nattel, S., Shiroshita-Takeshita, A., Brundel, B. J., and Rivard, L. (2005). Mechanisms of atrial fibrillation: lessons from animal models. Prog. Cardiovasc. Dis. 48, 9-28.

Nerbonne, J. M. (2004). Studying cardiac arrhythmias in the mouse-a reasonable model for probing mechanisms? Trends Cardiovasc. Med. 14, 83-93.

Nerbonne, J. M., Nichols, C. G., Schwarz, T. L., and Escande, D. (2001). Genetic manipulation of cardiac $\mathrm{k}(+)$ channel function in mice: what have we learned, and where do we go from here? Circ. Res. 89, 944-956.

Newby, K. H., Pisano, E., Krucoff, M. W., Green, C., and Natale,
A. (1996). Incidence and clinical relevance of the occurrence of bundle-branch block in patients treated with thrombolytic therapy. Circulation 94, 2424-2428.

Nishimaru, K., Makuta, R., Tanaka, Y., Tanaka, H., and Shigenobu, K. (2001). Pharmacological properties of excitation-contraction mechanisms in isolated mouse left atria. Pharmacology 62, 87-91.

Noujaim, S. F., Berenfeld, O., Kalifa, J., Cerrone, M., Nanthakumar, K., Atienza, F., Moreno, J., Mironov, S., and Jalife, J. (2007). Universal scaling law of electrical turbulence in the mammalian heart. Proc. Natl. Acad. Sci. U.S.A. 104, 20985-20989.

Noujaim, S. F., Lucca, E., Munoz, V., Persaud, D., Berenfeld, O., Meijler, F. L., and Jalife, J. (2004). From mouse to whale: a universal scaling relation for the pr interval of the electrocardiogram of mammals. Circulation 110, 2802-2808.

Nygren, A., Clark, R. B., Belke, D. D., Kondo, C., Giles, W. R., and Witkowski, F. X. (2000). Voltagesensitive dye mapping of activation and conduction in adult mouse hearts. Ann. Biomed. Eng. 28, 958-967.

Odening, K. E., Nerbonne, J. M., Bode, C., Zehender, M., and Brunner, M. (2009). In vivo effect of a dominant negative kv4.2 loss-of-function mutation eliminating i(to, f) on atrial refractoriness and atrial fibrillation in mice. Circ. J. 73, 461-467.

Oosthoek, P. W., Viragh, S., Mayen, A. E., van Kempen, M. J., Lamers, W. H., and Moorman, A. F. (1993). Immunohistochemical delineation of the conduction system. I: the sinoatrial node. Circ. Res. 73, 473-481.

Opthof, T. (2001). Function and structure of the mouse sinus node: nothing you can see that isn't shown. Cardiovasc. Res. 52, 1-4.

Osborn, J. J. (1953). Experimental hypothermia; respiratory and blood ph changes in relation to cardiac function. Am. J. Physiol. 175 389-398.

Pieske, B., Maier, L. S., Bers, D. M., and Hasenfuss, G. (1999). Ca ${ }^{2+}$ handling and sarcoplasmic reticulum $\mathrm{ca}^{2+}$ content in isolated failing and nonfailing human myocardium. Circ. Res. 85, 38-46.

Pogwizd, S. M., Qi, M., Yuan, W., Samarel, A. M., and Bers, D. M. (1999). Upregulation of $\mathrm{na}(+) / \mathrm{ca}(2+)$ exchanger expression and function in an arrhythmogenic rabbit model of heart failure. Circ. Res. 85, 1009-1019.
Pogwizd, S. M., Schlotthauer, K., Li, L., Yuan, W., and Bers, D. M. (2001). Arrhythmogenesis and contractile dysfunction in heart failure: roles of sodium-calcium exchange, inward rectifier potassium current, and residual beta-adrenergic responsiveness. Circ. Res. 88, 1159-1167.

Popovic, Z. B., Sun, J. P., Yamada, H., Drinko, J., Mauer, K., Greenberg, N. L., Cheng, Y., Moravec, C. S., Penn, M. S., Mazgalev, T. N., and Thomas, J. D. (2005). Differences in left ventricular long-axis function from mice to humans follow allometric scaling to ventricular size. J. Physiol. (Lond.) 568, 255-265.

Pott, C., Goldhaber, J. I., and Philipson, K. D. (2004). Genetic manipulation of cardiac $\mathrm{na}^{+} / \mathrm{ca}^{2+}$ exchange expression. Biochem. Biophys. Res. Commun. 322, 1336-1340.

Pott, C., Henderson, S. A., Goldhaber, J. I., and Philipson, K. D. (2007) $\mathrm{Na}^{+} / \mathrm{ca}^{2+}$ exchanger knockout mice: plasticity of cardiac excitation-contraction coupling. Ann. N.Y. Acad. Sci. 1099, 270-275.

Pott, C., Muszynski, A., Ruhe, M., Bogeholz, N., Schulte, J. S., Milberg, P., Monnig, G., Fabritz, L., Goldhaber, J. I., Breithardt, G., Schmitz, W., Philipson, K. D., Eckardt, L., Kirchhof, P., and Muller, F. U. (2012). Proarrhythmia in a non-failing murine model of cardiac-specific $\mathrm{na}^{+} / \mathrm{ca}^{2+}$ exchanger overexpression: whole heart and cellular mechanisms. Basic Res. Cardiol. 107, 247.

Prothero, J. (1979). Heart weight as a function of body weight in mammals. Growth 43, 139-150.

Qu, Y., Baroudi, G., Yue, Y., and Boutjdir, M. (2005). Novel molecular mechanism involving alphald (cav1.3) l-type calcium channel in autoimmune-associated sinus bradycardia. Circulation 111, 3034-3041.

Ranu, H. K., Terracciano, C. M., Davia, K., Bernobich, E., Chaudhri, B., Robinson, S. E., Bin Kang, Z., Hajjar, R. J., MacLeod, K. T., and Harding, S. E. (2002). Effects of $\mathrm{na}(+) / \mathrm{ca}(2+)$-exchanger overexpression on excitation-contraction coupling in adult rabbit ventricular myocytes. J. Mol. Cell. Cardiol. 34, 389-400.

Rensma, P. L., Allessie, M. A., Lammers, W. J., Bonke, F. I., and Schalij, M. J. (1988). Length of excitation wave and susceptibility to reentrant atrial arrhythmias in normal conscious dogs. Circ. Res. 62, 395-410.

Rentschler, S., Vaidya, D. M., Tamaddon, H., Degenhardt, K., Sassoon, D., Morley, G. E., Jalife, 
J., and Fishman, G. I. (2001). Visualization and functional characterization of the developing murine cardiac conduction system. Development 128, 1785-1792.

Reuter, H., Pott, C., Goldhaber, J. I., Henderson, S. A., Philipson, K. D., and Schwinger, R. H. (2005). $\mathrm{Na}(+)-\mathrm{Ca}^{2+}$ exchange in the regulation of cardiac excitationcontraction coupling. Cardiovasc. Res. 67, 198-207.

Rich, J. D., Thenappan, T., Freed, B., Patel, A. R., Thisted, R. A., Childers, R., and Archer, S. L. (2012). Qtc prolongation is associated with impaired right ventricular function and predicts mortality in pulmonary hypertension. Int. J. Cardiol. doi: 10.1016/j.ijcard.2012.03.071. [Epub ahead of print].

Roberts-Thomson, K. C., John, B., Worthley, S. G., Brooks, A. G., Stiles, M. K., Lau, D. H., Kuklik, P., Shipp, N. J., Kalman, J. M., and Sanders, P. (2009). Left atrial remodeling in patients with atrial septal defects. Heart Rhythm 6, 1000-1006.

Rossow, C. F., Dilly, K. W., and Santana, L. F. (2006). Differential calcineurin/nfatc3 activity contributes to the ito transmural gradient in the mouse heart. Circ. Res. 98, 1306-1313.

Ruan, Y., Liu, N., and Priori, S. G. (2009). Sodium channel mutations and arrhythmias. Nat. Rev. Cardiol. 6, 337-348.

Saba, S., Janczewski, A. M., Baker, L. C., Shusterman, V., Gursoy, E. C., Feldman, A. M., Salama, G., McTiernan, C. F., and London, B. (2005). Atrial contractile dysfunction, fibrosis, and arrhythmias in a mouse model of cardiomyopathy secondary to cardiac-specific overexpression of tumor necrosis factora. Am. J. Physiol. Heart Circ. Physiol. 289, H1456-H1467.

Saba, S., Wang, P. J., and Estes, N. A., 3rd. (2000). Invasive cardiac electrophysiology in the mouse: techniques and applications. Trends Cardiovasc. Med. 10, 122-132.

Sabir, I. N., Fraser, J. A., Cass, T. R., Grace, A. A., and Huang, C. L. (2007a). A quantitative analysis of the effect of cycle length on arrhythmogenicity in hypokalaemic langendorff-perfused murine hearts. Pflugers Arch. 454, 925-936.

Sabir, I. N., Fraser, J. A., Killeen, M. J., Grace, A. A., and Huang, C. L. (2007b). The contribution of refractoriness to arrhythmic substrate in hypokalemic langendorff-perfused murine hearts. Pflugers Arch. 454, 209-222.
Sabir, I. N., Killeen, M. J., Grace, A. A., and Huang, C. L. (2008). Ventricular arrhythmogenesis: insights from murine models. Prog. Biophys. Mol. Biol. 98, 208-218.

Sakamoto, J., Miura, T., Tsuchida, A., Fukuma, T., Hasegawa, T., and Shimamoto, K. (1999). Reperfusion arrhythmias in the murine heart: their characteristics and alteration after ischemic preconditioning. Basic Res. Cardiol. 94, 489-495.

Salama, G., Baker, L., Wolk, R., Barhanin, J., and London, B (2009). Arrhythmia phenotype in mouse models of human long qt. J. Interv. Card. Electrophysiol. 24, 77-87.

Salama, G., and London, B. (2007). Mouse models of long qt syndrome. J. Physiol. (Lond.) 578, 43-53.

Sanguinetti, M. C. (2010). Herg1 channelopathies. Pflugers Arch. 460, 265-276.

Sato, D., Xie, L. H., Sovari, A. A. Tran, D. X., Morita, N., Xie, F., Karagueuzian, H., Garfinkel, A., Weiss, J. N., and Qu, Z. (2009). Synchronization of chaotic early afterdepolarizations in the genesis of cardiac arrhythmias. Proc. Natl. Acad. Sci. U.S.A. 106, 2983-2988.

Sawaya, S. E., Rajawat, Y. S., Rami, T. G., Szalai, G., Price, R. L., Sivasubramanian, N., Mann, D. L., and Khoury, D. S. (2007). Downregulation of connexin40 and increased prevalence of atrial arrhythmias in transgenic mice with cardiac-restricted overexpression of tumor necrosis factor. Am. J. Physiol. Heart Circ. Physiol. 292, H1561-H1567.

Schauerte, P., Mischke, K., Plisiene, J., Waldmann, M., Zarse, M., Stellbrink, C., Schimpf, T. Knackstedt, C., Sinha, A., and Hanrath, P. (2001). Catheter stimulation of cardiac parasympathetic nerves in humans: a novel approach to the cardiac autonomic nervous system. Circulation 104, 2430-2435.

Schillinger, W., Janssen, P. M., Emami, S., Henderson, S. A., Ross, R. S. Teucher, N., Zeitz, O., Philipson, K. D., Prestle, J., and Hasenfuss, G. (2000). Impaired contractile performance of cultured rabbit ventricular myocytes after adenoviral gene transfer of na( + $\mathrm{ca}(2+)$ exchanger. Circ. Res. 87, 581-587.

Schott, J. J., Benson, D. W., Basson, C. T., Pease, W., Silberbach, G. M., Moak, J. P., Maron, B. J., Seidman, C. E., and Seidman, J. G. (1998). Congenital heart disease caused by mutations in the transcription factor nkx2-5. Science 281, 108-111.
Schotten, U., Verheule, S., Kirchhof, P., and Goette, A. (2011). Pathophysiological mechanisms of atrial fibrillation: a translationa appraisal. Physiol. Rev. 91, 265-325.

Schrickel, J. W., Bielik, H., Yang, A., Schimpf, R., Shlevkov, N., Burkhardt, D., Meyer, R., Grohe, C. Fink, K., Tiemann, K., Luderitz, B. and Lewalter, T. (2002). Induction of atrial fibrillation in mice by rapid transesophageal atrial pacing. Basic Res. Cardiol. 97, 452-460.

Schrickel, J. W., Brixius, K., Herr, C. Clemen, C. S., Sasse, P., Reetz, K., Grohe, C., Meyer, R., Tiemann, K. Schroder, R., Bloch, W., Nickenig, G., Fleischmann, B. K., Noegel, A A., Schwinger, R. H., and Lewalter, T. (2007). Enhanced heterogeneity of myocardial conduction and severe cardiac electrical instability in annexin a7-deficient mice. Cardiovasc. Res. 76, 257-268.

Schrickel, J. W., Kreuzberg, M. M., Ghanem, A., Kim, J. S., Linhart, M. Andrie, R., Tiemann, K., Nickenig, G., Lewalter, T., and Willecke, $\mathrm{K}$. (2009). Normal impulse propagation in the atrioventricular conduction system of $\mathrm{cx} 30.2 / \mathrm{cx} 40$ double deficient mice. J. Mol. Cell. Cardiol. 46, 644-652.

Shattock, M. J., and Bers, D. M. (1989) Rat vs. Rabbit ventricle: Ca flux and intracellular na assessed by ion-selective microelectrodes. Am J. Physiol. 256, C813-C822.

Shaw, R. M., and Rudy, Y. (1997). Ionic mechanisms of propagation in cardiac tissue. Roles of the sodium and l-type calcium currents during reduced excitability and decreased gap junction coupling. Circ. Res. 81 727-741.

Sheng, H., Laskowitz, D. T., Mackensen, G. B., Kudo, M., Pearlstein, R. D., and Warner, D. S. (1999). Apolipoprotein e deficiency worsens outcome from global cerebra ischemia in the mouse. Stroke 30 1118-1124

Simon, A. M., Goodenough, D. A., and Paul, D. L. (1998). Mice lacking connexin40 have cardiac conduction abnormalities characteristic of atrioventricular block and bundle branch block. Curr. Biol. 8, 295-298.

Sizarov, A., Devalla, H. D., Anderson, R. H., Passier, R., Christoffels, V. M., and Moorman, A. F. (2011). Molecular analysis of patterning of conduction tissues in the developing human heart. Circ. Arrhythm Electrophysiol. 4, 532-542.

Spach, M. S., and Josephson, M. E. (1994). Initiating reentry: the role of nonuniform anisotropy in small circuits. J. Cardiovasc. Electrophysiol. 5, 182-209.

Speakman, J. R., Selman, C., McLaren, J. S., and Harper, E. J. (2002). Living fast, dying when? The link between aging and energetics. J. Nutr. 132, 1583S-1597S.

Stables, C. L., and Curtis, M. J. (2009). Development and characterization of a mouse in vitro model of ischaemia-induced ventricular fibrillation. Cardiovasc. Res. $83,397-404$.

Stein, M., van Veen, T. A., Remme, C. A., Boulaksil, M., Noorman, M., van Stuijvenberg, L., van der Nagel, R., Bezzina, C. R., Hauer, R. N., de Bakker, J. M., and van Rijen, H. V. (2009). Combined reduction of intercellular coupling and membrane excitability differentially affects transverse and longitudinal cardiac conduction. Cardiovasc. Res. $83,52-60$.

Stein, R., Medeiros, C. M., Rosito, G. A., Zimerman, L. I., and Ribeiro, J. P. (2002). Intrinsic sinus and atrioventricular node electrophysiologic adaptations in endurance athletes. J. Am. Coll. Cardiol. 39, 1033-1038.

Stepien, R. L., Hinchcliff, K. W., Constable, P. D., and Olson, J. (1998). Effect of endurance training on cardiac morphology in alaskan sled dogs. J. Appl. Physiol. 85, 1368-1375.

Stiles, M. K., Wong, C. X., John, B., Kuklik, P., Brooks, A. G., Lau, D. H., Dimitri, H., Wilson, L., Young, G. D., and Sanders, P. (2010) Characterization of atrial remodeling studied remote from episodes of typical atrial flutter. Am. J. Cardiol. 106, 528-534.

Studer, R., Reinecke, H., Bilger, J., Eschenhagen, T., Bohm, M., Hasenfuss, G., Just, H., Holtz, J., and Drexler, H. (1994). Gene expression of the cardiac na(+) $\mathrm{Ca}^{2+}$ exchanger in end-stage human heart failure. Circ. Res. 75, 443-453. Swaminathan, P. D., Purohit, A., Soni, S., Voigt, N., Singh, M. V., Glukhov, A. V., Gao, Z., He, B. J., Luczak, E. D., Joiner, M. L., Kutschke, W., Yang, J., Donahue, J. K., Weiss, R. M. Grumbach, I. M., Ogawa, M., Chen, P. S., Efimov, I., Dobrev, D., Mohler P. J., Hund, T. J., and Anderson, M. E. (2011). Oxidized camkii causes cardiac sinus node dysfunction in mice. J. Clin. Invest. 121, 3277-3288.

Tamaddon, H. S., Vaidya, D., Simon, A. M., Paul, D. L., Jalife, J., and Morley, G. E. (2000). High-resolution optical mapping of the right bundle branch in connexin 40 knockout mice reveals slow conduction in the 
specialized conduction system. Circ. Res. 87, 929-936.

Terracciano, C. M., Souza, A. I., Philipson, K. D., and MacLeod, K. T. (1998). $\mathrm{Na}^{+}-\mathrm{ca}^{2+}$ exchange and sarcoplasmic reticular $\mathrm{ca}^{2+}$ regulation in ventricular myocytes from transgenic mice overexpressing the $\mathrm{na}^{+}-\mathrm{Ca}^{2+}$ exchanger. J. Physiol. (Lond.) 512(Pt 3), 651-667.

Thapar, M. K., and Gillette, P. C. (1979). Dual atrioventricular nodal pathways: a common electrophysiologic response in children. Circulation 60, 1369-1374.

Thomas, S. A., Schuessler, R. B., Berul, C. I., Beardslee, M. A., Beyer, E. C., Mendelsohn, M. E., and Saffitz, J. E. (1998). Disparate effects of deficient expression of connexin 43 on atrial and ventricular conduction: evidence for chamber-specific molecular determinants of conduction. Circulation 97, 686-691.

Toischer, K., Rokita, A. G., Unsold, B., Zhu, W., Kararigas, G., Sossalla, S., Reuter, S. P., Becker, A., Teucher, N., Seidler, T., Grebe, C., Preuss, L., Gupta, S. N., Schmidt, K., Lehnart, S. E., Kruger, M., Linke, W. A., Backs, J., Regitz-Zagrosek, V., Schafer, K., Field, L. J., Maier, L. S., and Hasenfuss, G. (2010). Differential cardiac remodeling in preload versus afterload. Circulation 122, 993-1003.

Trepanier-Boulay, V., Lupien, M. A., St-Michel, C., and Fiset, C. (2004). Postnatal development of atrial repolarization in the mouse. Cardiovasc. Res. 64, 84-93.

Tuteja, D., Rafizadeh, S., Timofeyev, V., Wang, S., Zhang, Z., Li, N., Mateo, R. K., Singapuri, A., Young, J. N., Knowlton, A. A., and Chiamvimonvat, N. (2010). Cardiac small conductance $\mathrm{Ca}^{2+}$-activated $\mathrm{k}^{+}$channel subunits form heteromultimers via the coiled-coil domains in the $c$ termini of the channels. Circ. Res. 107, 851-859.

Tuzcu, E. M., Emre, A., Goormastic, M., Loop, F. D., and Underwood, D. A. (1990). Incidence and prognostic significance of intraventricular conduction abnormalities after coronary bypass surgery. J. Am. Coll. Cardiol. 16, 607-610.

Vaidya, D., Morley, G. E., Samie, F. H., and Jalife, J. (1999). Reentry and fibrillation in the mouse heart. A challenge to the critical mass hypothesis. Circ. Res. 85, 174-181.

van den Borne, S. W., van de Schans, V. A., Strzelecka, A. E., Vervoort-Peters, H. T., Lijnen, P. M., Cleutjens, J. P., Smits, J. F., Daemen, M. J., Janssen, B. J., and Blankesteijn, W. M. (2009). Mouse strain determines the outcome of wound healing after myocardial infarction. Cardiovasc. Res. 84, 273-282.

VanderBrink, B. A., Link, M. S., Aronovitz, M. J., Saba, S., Sloan, S. B., Homoud, M. K., Estes, I. N., and Wang, P. J. (1999). Assessment of atrioventricular nodal physiology in the mouse. J. Interv. Card. Electrophysiol. 3, 207-212.

VanderBrink, B. A., Sellitto, C., Saba, S., Link, M. S., Zhu, W., Homoud, M. K., Estes, N. A. 3rd., Paul, D. L., and Wang, P. J. (2000). Connexin40deficient mice exhibit atrioventricular nodal and infra-hisian conduction abnormalities. J. Cardiovasc. Electrophysiol. 11, 1270-1276.

Van Loon, G., Duytschaever, M., Tavernier, R., Fonteyne, W. Jordaens, L., and Deprez, P. (2002). An equine model of chronic atrial fibrillation: methodology. Vet. J. 164, 142-150.

van Rijen, H. V., Eckardt, D., Degen, J., Theis, M., Ott, T., Willecke, K., Jongsma, H. J., Opthof, T., and de Bakker, J. M. (2004). Slow conduction and enhanced anisotropy increase the propensity for ventricular tachyarrhythmias in adult mice with induced deletion of connexin43. Circulation 109, 1048-1055.

van Rijen, H. V., van Veen, T. A., van Kempen, M. J., Wilms-Schopman, F. J., Potse, M., Krueger, O., Willecke, K., Opthof, T., Jongsma, H. J., and de Bakker, J. M. (2001). Impaired conduction in the bundle branches of mouse hearts lacking the gap junction protein connexin40. Circulation 103, 1591-1598.

van Veen, T. A., Stein, M., Royer, A., Le Quang, K., Charpentier, F., Colledge, W. H., Huang, C. L., Wilders, R., Grace, A. A., Escande, D., de Bakker, J. M., and van Rijen, H. V. (2005). Impaired impulse propagation in scn5a-knockout mice: combined contribution of excitability, connexin expression, and tissue architecture in relation to aging. Circulation 112, 1927-1935.

van Veen, T. A., van Rijen, H. V., van Kempen, M. J., Miquerol, L., Opthof, T., Gros, D., Vos, M. A., Jongsma, H. J., and de Bakker, J. M. (2005). Discontinuous conduction in mouse bundle branches is caused by bundle-branch architecture. Circulation 112, 2235-2244.

Veldkamp, M. W., Wilders, R., Baartscheer, A., Zegers, J. G., Bezzina, C. R., and Wilde, A. A. (2003). Contribution of sodium channel mutations to bradycardia and sinus node dysfunction in lqt3 families. Circ. Res. 92, 976-983.

Verheijck, E. E., van Kempen, M. J., Veereschild, M., Lurvink, J., Jongsma, H. J., and Bouman, L. N. (2001). Electrophysiological features of the mouse sinoatrial node in relation to connexin distribution. Cardiovasc. Res. 52, 40-50.

Verheule, S., Sato, T., Everett Tt, Engle, S. K., Otten, D., Rubartvon der Lohe, M., Nakajima, $\mathrm{H}$ O., Nakajima, H., Field, L. J., and Olgin, J. E. (2004). Increased vulnerability to atrial fibrillation in transgenic mice with selective atrial fibrosis caused by overexpression of tof-beta1. Circ. Res. 94, 1458-1465.

Verheule, S., Tuyls, E., van Hunnik, A., Kuiper, M., Schotten, U., and Allessie, M. (2010). Fibrillatory conduction in the atrial free walls of goats in persistent and permanent atrial fibrillation. Circ. Arrhythm Electrophysiol. 3, 590-599.

Verheule, S., van Batenburg, C. A., Coenjaerts, F. E., Kirchhoff, S. Willecke, K., and Jongsma, H. J. (1999). Cardiac conduction abnormalities in mice lacking the gap junction protein connexin 40 . J. Cardiovasc. Electrophysiol. 10 , 1380-1389.

Vinet, L., Pezet, M., Bito, V., Briec, F., Biesmans, L., Rouet-Benzineb, P. Gellen, B., Previlon, M., Chimenti, S., Vilaine, J. P., Charpentier, F., Sipido, K. R., and Mercadier, J. J. (2012). Cardiac fkbp12.6 overexpression protects against triggered ventricular tachycardia in pressure overloaded mouse hearts. Basic Res. Cardiol. 107, 246.

Vornanen, M. (1992). Maximum heart rate of soricine shrews: correlation with contractile properties and myosin composition. Am. J. Physiol. 262, R842-R851.

Wakimoto, H., Maguire, C. T., Kovoor, P., Hammer, P. E., Gehrmann, J., Triedman, J. K., and Berul, C. I. (2001). Induction of atrial tachycardia and fibrillation in the mouse heart. Cardiovasc. Res. 50, 463-473.

Waldek, S. (2003). Pr interval and the response to enzyme-replacement therapy for fabry's disease. N. Engl. J. Med. 348, 1186-1187.

Waldeyer, C., Fabritz, L., Fortmueller, L., Gerss, J., Damke, D., Blana, A., Laakmann, S., Kreienkamp, N., Volkery, D., Breithardt, G., and Kirchhof, P. (2009). Regional, age-dependent, and genotypedependent differences in ventricular action potential duration and activation time in 410 langendorffperfused mouse hearts. Basic Res. Cardiol. 104, 523-533.
Wang, Y., Cheng, J., Joyner, R. W., Wagner, M. B., and Hill, J. A. (2006). Remodeling of early-phase repolarization: a mechanism of abnormal impulse conduction in heart failure. Circulation 113, 1849-1856.

Wehrens, X. H., Kirchhoff, S., and Doevendans, P. A. (2000). Mouse electrocardiography: an interval of thirty years. Cardiovasc. Res. 45, 231-237.

Wessels, A., and Sedmera, D. (2003). Developmental anatomy of the heart: a tale of mice and man. Physiol. Genomics 15, 165-176.

West, G. B., Brown, J. H., and Enquist, B. J. (1997). A general model for the origin of allometric scaling laws in biology. Science 276, 122-126.

West, G. B., Brown, J. H., and Enquist, B. J. (1999). The fourth dimension of life: fractal geometry and allometric scaling of organisms. Science 284, 1677-1679.

Wickman, K., Nemec, J., Gendler, S. J., and Clapham, D. E. (1998). Abnormal heart rate regulation in girk4 knockout mice. Neuron 20, 103-114.

Wiener, N., and Rosenblueth, A. (1946). The mathematical formulation of the problem of conduction of impulses in a network of connected excitable elements, specifically in cardiac muscle. Arch. Inst. Cardiol. Mex. 16, 205-265.

Wiese, C., Grieskamp, T., Airik, R., Mommersteeg, M. T., Gardiwal, A., de Gier-de Vries, C., SchusterGossler, K., Moorman, A. F., Kispert, A., and Christoffels, V. M. (2009). Formation of the sinus node head and differentiation of sinus node myocardium are independently regulated by tbx 18 and tbx 3 . Circ. Res. 104, 388-397.

Wijffels, M. C., Kirchhof, C. J., Dorland, R., Power, J., and Allessie, M. A. (1997). Electrical remodeling due to atrial fibrillation in chronically instrumented conscious goats: roles of neurohumoral changes, ischemia, atrial stretch, and high rate of electrical activation. Circulation 96, 3710-3720.

Xiao, H. D., Fuchs, S., Campbell, D. J., Lewis, W., Dudley, S. C., Jr., Kasi, V. S., Hoit, B. D., Keshelava, G., Zhao, H., Capecchi, M. R., and Bernstein, K. E. (2004). Mice with cardiac-restricted angiotensinconverting enzyme (ace) have atrial enlargement, cardiac arrhythmia, and sudden death. Am. J. Pathol. $165,1019-1032$.

Xu, H., Guo, W., and Nerbonne, J. M. (1999). Four kinetically distinct depolarization-activated $\mathrm{k}^{+}$currents in adult mouse ventricular 
myocytes. J. Gen. Physiol. 113, 661-678.

Yao, A., Su, Z., Nonaka, A., Zubair, I., Lu, L., Philipson, K. D., Bridge, J. H., and Barry, W. H. (1998). Effects of overexpression of the $\mathrm{na}^{+}-\mathrm{ca}^{2+}$ exchanger on $[\mathrm{ca} 2+]$ i transients in murine ventricular myocytes. Circ. Res. 82, 657-665.

Zhang, G. Q., and Zhang, W. (2009). Heart rate, lifespan, and mortality risk. Ageing Res. Rev. 8, 52-60.

Zhang, Q., Timofeyev, V., Qiu, H., Lu, L., Li, N., Singapuri, A., Torado, C. L., Shin, H. S., and Chiamvimonvat, N. (2011). Expression and roles of cav1.3 (alphald) 1-type ca(2)+ channel in atrioventricular node automaticity. J. Mol. Cell. Cardiol. 50, 194-202.

Zhang, Z., He, Y., Tuteja, D., Xu, D., Timofeyev, V., Zhang, Q., Glatter,
K. A., Xu, Y., Shin, H. S., Low, R., and Chiamvimonvat, N. (2005). Functional roles of cav1.3(alphald) calcium channels in atria: insights gained from gene-targeted null mutant mice. Circulation 112, 1936-1944.

Zhang, Z., Xu, Y., Song, H., Rodriguez, J., Tuteja, D., Namkung, Y., Shin, H. S., and Chiamvimonvat, N. (2002). Functional roles of $\mathrm{ca}(\mathrm{v}) 1.3$ (alpha(1d)) calcium channel in sinoatrial nodes: insight gained using gene-targeted null mutant mice. Circ. Res. 90, 981-987.

Zhou, J., Kodirov, S., Murata, M. Buckett, P. D., Nerbonne, J. M., and Koren, G. (2003). Regional upregulation of $\mathrm{kv} 2.1$-encoded current, ik, slow2, in kv1dn mice is abolished by crossbreeding with kv2dn mice. Am. J.
Physiol. Heart Circ. Physiol. 284, H491-H500.

Zhu, W., Saba, S., Link, M. S., Bak, E., Homoud, M. K., Estes, N. A. 3rd., Paul, D. L., and Wang, P. J. (2005). Atrioventricular nodal reverse facilitation in connexin40deficient mice. Heart Rhythm 2, 1231-1237.

Zou, R., Kneller, J., Leon, L. J., and Nattel, S. (2005). Substrate size as a determinant of fibrillatory activity maintenance in a mathematical model of canine atrium. Am. J. Physiol. Heart Circ. Physiol. 289, H1002-H1012.

Conflict of Interest Statement: The authors declare that the research was conducted in the absence of any commercial or financial relationships that could be construed as a potential conflict of interest.

Received: 02 May 2012; accepted: 09 August 2012; published online: 05 September 2012.

Citation: Kaese S and Verheule S (2012) Cardiac electrophysiology in mice: a matter of size. Front. Physio. 3:345. doi: 10.3389/fphys.2012.00345

This article was submitted to Frontiers in Cardiac Electrophysiology, a specialty of Frontiers in Physiology.

Copyright (c) 2012 Kaese and Verheule. This is an open-access article distributed under the terms of the Creative Commons Attribution License, which permits use, distribution and reproduction in other forums, provided the original authors and source are credited and subject to any copyright notices concerning any third-party graphics etc. 